\title{
A process-based Sphagnum plant-functional-type model for implementation in the TRIFFID Dynamic Global Vegetation Model
} Richard Coppell ${ }^{1}$, Emanuel Gloor ${ }^{1}$, Joseph Holden ${ }^{1}$

${ }^{1}$ water@leeds, School of Geography, University of Leeds, Leeds, LS2 9JT, UK

Correspondence to: Richard Coppell (r.coppell@leeds.ac.uk)

\begin{abstract}
Peatlands are important carbon stores and Sphagnum moss represents a critical peatland genus contributing to carbon exchange and storage. However, gas fluxes in Sphagnum-dominated systems are poorly represented in Dynamic Global Vegetation Models (DGVMs) which simulate, via incorporation of Plant Functional Types (PFTs), biogeochemical and energy fluxes between vegetation, the land surface and the atmosphere. Mechanisms characterised by PFTs within DGVMs include photosynthesis, respiration and competition and, in more recent DGVMs, sub-daily gas-exchange processes regulated by leaf stomata. However, Sphagnum, like all mosses, are non-vascular plants and do not exhibit stomatal regulation. In order to achieve a level of process detail consistent with existing vascular vegetation PFTs within DGVMs, this paper describes a new process-based non-vascular-PFT model that is implemented within the TRIFFID DGVM used by the JULES land surface model. The new PFT model was tested against extant published field and laboratory studies of peat assemblage-net primary productivity, assemblage-gross primary productivity, assemblage respiration, water-table position, incoming photosynthetically active radiation, temperature, and canopy dark respiration. The PFT model's parameters were roughly tuned and the PFT model easily produced curves of the correct shape for peat assemblage-net primary productivity against watertable position, incoming photosynthetically active radiation and temperature, suggesting that it replicates the internal productivity mechanism of Sphagnum for the first time. Minor modifications should also allow it to be used across a range of other bryophytes enabling this non-vascular PFT model to have enhanced functionality.
\end{abstract}

\section{Introduction}

Around 600Gt of carbon exists in peat that has accumulated in temperate and cold biomes since the Last Glacial Maximum (Yu et al. 2010, Yu 2011). This is about 25\% of the carbon stored in deep soils (Jobaggy \& Jackson 2000). Peat accumulates in areas where precipitation exceeds evapotranspiration and there is impeded drainage due to the landscape configuration or underlying impermeable layers. There is uncertainty about feedback mechanisms between peatland systems and future climate change. For example, warming may enhance decomposition rates of peat and thus release of carbon to the atmosphere, but it may also enhance net primary production (NPP) and thus mitigate anthropogenic greenhouse warming (Loisel et al. 2012; Charman et al. 2013; O'Connor et al. 2010). This means that the net result on greenhouse gas fluxes regionally and globally is not clear and there is therefore a need for improved climate-land surface feedback models that incorporate such peatland processes (Limpens et al. 2008; Frolking et al. 2009; Hayman et al. 2014). 
https://doi.org/10.5194/gmd-2019-51

Preprint. Discussion started: 9 July 2019

(c) Author(s) 2019. CC BY 4.0 License.

(c) (i)

Dynamic Global Vegetation Models (DGVMs) simulate carbon, water and energy fluxes between vegetation, the atmosphere and the land surface (e.g. Clark et al. 2011; Haxeltine \& Prentice, 1996; Sitch et al. 2003). DGVMs may be run independently with prescribed climate or they can be coupled to climate models. For example, the TRIFFID DGVM is a sub-model of the

5 JULES land surface model which is in turn part of the Hadley Centre climate model (Clark et al. 2011; Pope et al. 2000). As such, DGVMs could be used in understanding past and future change in peatlands and their interactions with global climate. DGVMs simulate the effects of a limited number of vegetation classes (rather than every single species) in each horizontal grid square of the model, reflecting the assumption that regional vegetation assemblages are dominated by a small number of Plant Functional Types (PFTs) (Brovkin et al. 1997; Haxeltine \& Prentice, 1996). The main vegetation processes represented

10 in DGVMs include photosynthesis and accumulation of atmospheric carbon in plant tissues, respiration, the accumulation of litter from dead plant material and plant competition. Therefore, for use in peatlands, DGVMs require appropriate incorporation of dominant peatland PFTs, and their associated relevant carbon exchange and litter accumulation processes.

In the current generation of DGVMs, vegetation-atmosphere $\mathrm{CO}_{2}$ exchange is commonly represented at sub-daily time-steps,

15 incorporating regulation of gas exchange in vascular plants by leaf stomata that close in response to moisture deficit in the leaf (e.g. Cox, et al. 1998; Clark et al. 2011; Gao et al. 2013). Sphagnum mosses are a dominant genus within peatlands. At least half of the carbon in northern peatlands is dead matter from Sphagnum (Clymo \& Hayward, 1982). However, there is a key problem with incorporating Sphagnum into DGVMs: Sphagnum is a non-vascular plant that lacks stomatal gas-exchange. Therefore, Sphagnum mosses show quite different responses of photosynthesis and respiration to changes in their immediate environment compared to vascular plants and this means they cannot be simply incorporated into current DGVMs. For example, Riutta et al. (2007) examined gross primary production (GPP) of Sphagnum compared to vascular wetland plants, for different environmental conditions. Unlike vascular wetland plants, Sphagnum GPP showed a high tolerance to waterlogging, and little short-term temperature-dependence with much higher rates of production for temperatures below $20^{\circ} \mathrm{C}$ than vascular wetland plants.

Sphagnum also causes changes in the local physical and chemical environment, slowing the rate of decay (Rydin et al 2006). Sphagnum cell walls and litter contain insoluble polysaccharides that inhibit microbial mineralisation, while the release of uronic acids from Sphagnum acidifies the soil water and hinders the decay of adjacent litter from other plants (Hájek et al. 2010; Van Breemen 1995). Thus, Sphagnum is associated with high rates of plant litter accumulation in cool, wet areas resulting in peatland extents and depths that are larger than they would be without Sphagnum (Rydin \& Jeglum, 2006).

Given the importance of Sphagnum to peatland systems and the global carbon store, it is essential that Sphagnum is appropriately incorporated into the latest-generation DGVMs. Variations do exist in Sphagnum assemblage behaviour - for example, wetland sub-environments such as hummocks, hollows and pools have different assemblages of Sphagnum species 
https://doi.org/10.5194/gmd-2019-51

Preprint. Discussion started: 9 July 2019

(c) Author(s) 2019. CC BY 4.0 License.

although similarities also exist (Rydin 1986). However, DGVMs also require the number of PFTs to be limited, and previous studies (Druel et al. 2017; Qiu et al. 2018; Wania 2009a, 2009b; Yurova et al. 2007) have found improved fit of peatland ecosystem NPP with field $\mathrm{CO}_{2}$ exchange data using very simple Sphagnum PFTs. Therefore, we sought to develop, as a first attempt, a single process-based Sphagnum PFT that has a higher level of detail than these previous studies in a currentgeneration DGVM, having a consistent level of detail with existing vascular PFTs in the same DGVM. We chose the TRIFFID DGVM because it has very widespread use as part of JULES and the Hadley Centre Climate Model and it has been validated across many biomes (e.g. Clark \& Gedney, 2008; Cox et al 1998; Cox et al 2001; Hughes et al 2004; Harper et al 2018). Despite its widespread use, however, a major advancement is needed in the functionality of the model by improving the representation of the peatland biome. This is because it does not have any module that reproduces the vegetation or hydrology

10 mechanisms of peatlands (e.g. see Harper et al's (2018) description of the vegetation types represented in a very recent version of JULES).

Other DGVMs that have simple Sphagnum PFTs incorporated are coupled to a peat-soil-model, and were validated as whole ecosystems not as individual PFTs. A Sphagnum plant respiration and production model was developed by Yurova et al (2007)

15 as a modification of the Lund-Potsdam-Jena General Ecosystem Simulator (LPJ-GUESS). The LPJ base-model is simpler than TRIFFID, lacking detail such as leaf-gas-conduction and therefore not making any model-code-level distinction between vascular and non-vascular plants. Therefore, LPJ's Sphagnum PFT just has different parameters without changing the basecode of the model. The ORCHIDEE-PEAT model (Qiu et al. 2018) uses its existing C3 grass PFT with stomatal gas-regulation to simulate peatland NPP, calibrating it at each site using locally measured $\mathrm{V}_{\max }$ values (a key enzyme-controlled reaction rate

20 in photosynthesis dependent on the local environment as well as inherited properties of the plants). This local calibration against $\mathrm{V}_{\max }$ is recognised by the authors as a major adjustment factor to cover multiple uncertain parameters, adjusting for the fact that non-vascular properties of some of the vegetation in the test-sites are not accommodated in the model code. Similarly, Druel et al (2018) in another version of ORCHIDEE used its existing C3 grass vascular model and parameters to simulate nonvascular plants (including all mosses as well as Sphagnum in a single PFT), modifying the parameters to minimise the effects of stomatal regulation of leaf-gas exchange from the base vascular model, but short of changing the base model itself to resemble the non-vascular function of Sphagnum. These ORCHIDEE and LPJ sub-models represented whole peat-ecosystems including soil-processes and were validated against $\mathrm{CO}_{2}$-eddy-covariance measurements; they were not validated at the level of isolated individual PFTs. In this study, we have focussed on specific Sphagnum-processes instead of trying to approximate Sphagnum's behaviour without changing the base model. This is to try to replicate Sphagnum's production and respiration

30 mechanism in more detail than other DGVMs have done so far, at this isolated PFT level. For the first time with any nonvascular PFT as far as we are aware, this model should permit direct comparison with organism-level productivity and respiration measurements, permitting the first attempt at a general model for Sphagnum photosynthesis and respiration at this higher level of detail. Since this work does not include the development of a coupled peat-soil model then the model-output 
https://doi.org/10.5194/gmd-2019-51

Preprint. Discussion started: 9 July 2019

(c) Author(s) 2019. CC BY 4.0 License.

(c) (i)

cannot be validated against $\mathrm{CO}_{2}$ eddy-covariance measurements (such as used by Qiu et al 2018) since we are not simulating whole-ecosystem NPP.

An increased level of functional detail is introduced in section 2 where we outline the key biological and physical traits of

5 Sphagnum that require new functions in TRIFFID, with an explanation of how we have incorporated specific Sphagnum traits within TRIFFID. We present the outputs of model runs in section 3. We test the model with available data from recently published studies, which measured assemblage-NPP, assemblage-GPP, assemblage respiration, WTP (water-table position), PAR (photosynthetically active radiation), temperature, canopy dark respiration and $\mathrm{V}_{\max }$. Canopy dark respiration is the respiration in leaves that occurs in cell mitochondria as opposed to photosynthesising cell components, and $\mathrm{V}_{\max }$ is the

10 maximum rate of carboxylation of rubisco, which is a key photosynthesising enzyme that controls primary production. Section 4 concludes by outlining further potential developments of the new Sphagnum PFT model and its wider use.

\section{Model development and theory}

Sphagnum exchanges gas directly through cell walls. Individual Sphagnum stems and leaves are spongy and porous, and they grow in tightly packed assemblages. The surface shoots of these Sphagnum assemblages have been observed to retain a lot of

15 water in this way, having up to ten times as much water by mass as the dry-mass of the plants themselves (Hayward \& Clymo 1982; Rydin 1985; Rydin \& Jeglum 2006; Strack et al. 2009). This water is held and sucked up by capillarity in the surface Sphagnum matter and deeper Sphagnum litter (e.g. Charman 2002; Rydin \& Jeglum 2006; Van Breemen 1995). These characteristics mean that Sphagnum plants have clear differences to vascular plants in terms of physical shape and the processes that occur within them. Where these characteristics are relevant to simulating photosynthesis and plant respiration $\left(\mathrm{R}_{\mathrm{p}}\right)$ in a

20 PFT model, they are described in Table 1 in comparison to a pre-existing example of a vascular PFT that has been developed and tested in TRIFFID. Table 1, therefore, illustrates the basis for modifications that are required to incorporate Sphagnum within the TRIFFID DGVM. 
Table 1. A comparison of Sphagnum processes with those of typical C3 vascular plants

\begin{tabular}{ll}
\hline Process & C3 Graminoids \\
\hline Life form & Able to survive as individuals across wide range \\
& of soil conditions, although few survive long \\
& periods total saturation. Consist of roots (below \\
& ground) and the shoot that has stems, leaves and \\
& seed-heads. Often exist in large assemblages \\
& with other grasses and other vascular plants.
\end{tabular}

Sphagnum

Only ever occur in assemblages. Only exist where the soil normally has high moisture content and some species tolerate long periods of total saturation. Consist of closely packed branching stems. Along the stems are 'stem leaves' and the whole assemblage forms 'mats' where only the top few $\mathrm{cm}$ (the capitulum) receive enough light to photosynthesise.

\begin{tabular}{lll}
\hline Leaf anatomy & $\begin{array}{l}\text { Several cell layers, water impermeable cuticula, } \\
\text { punctuated with stomata. }\end{array}$ & $\begin{array}{l}\text { Leaf is single cell layer containing } \\
\text { photosynthesising and non- } \\
\text { photosynthesising cells with no } \\
\text { stomata. }\end{array}$ \\
& &
\end{tabular}

Leaf-air gas exchange Regulated by stomata that open fully or partially to specifically allow transpiration, but also conserve moisture by closing up under water-stress of the leaf or when there are strong humidity gradients.

\begin{tabular}{l} 
Photosynthesis \\
\hline $\begin{array}{l}\text { Water uptake and } \\
\text { transport }\end{array}$
\end{tabular}
C3 pathway

Constant gas exchange via molecular diffusion between photosynthesising cells and either directly with atmosphere or via thin water-film between leaf and atmosphere.

C3 pathway

Xylem vessels connect the roots vertically to the leaves. Strongly negative water potential at leaf surface is due to transpiration from the leaf. Water drawn up under strong hydraulic gradients from roots. Waxy cuticula leaf surface prevents direct leaf-water uptake.

\begin{tabular}{|c|c|}
\hline $\begin{array}{l}\text { Water storage and } \\
\text { stress }\end{array}$ & $\begin{array}{l}\text { Not desiccation tolerant. Metabolism might } \\
\text { slow under stress but needs to be maintained. } \\
\text { Water stored in living cells; high internal water } \\
\text { storage is a requirement for plant structure and } \\
\text { survival. Stomata close during drought to limit } \\
\text { transpiration but high soil water tension leads to } \\
\text { the plant being unable to access soil water, } \\
\text { resulting in cell wall collapse and mortality. }\end{array}$ \\
\hline
\end{tabular}

Water uptake and release from much of the plant surface. Vertical water transport occurs up the exterior of the stem, including deeper dead stem material, and underlying peat by capillary action. No clear dividing line between these formations. Assemblages also intercept and absorb water from direct precipitation.

Desiccation tolerant. Metabolism suspended until wet periods return. Quick to recover after drought. Water storage in spongy assemblages. The leaves consist of small living chlorophyllose cells and large structural dead hyaline cells that store lots of water. Closed canopy shelters underlying peat from direct sunlight. Peat typically has very high moisture content even after drought. 
https://doi.org/10.5194/gmd-2019-51

Preprint. Discussion started: 9 July 2019

(c) Author(s) 2019. CC BY 4.0 License.

(c) (i)

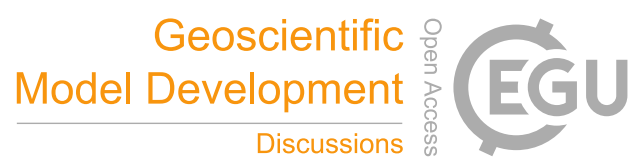

\subsection{Life form}

Sphagnum assemblages exist at a spatial scale of up to $100 \mathrm{~km}^{2}$ (e.g. Baird et al. 2009; Bragg \& Lindsay 2003; Rydin \& Jeglum 2006). Sphagnum assemblages are closely packed 'mats' within which individuals, of the order of $10 \mathrm{~cm}$ in length, are vertically oriented. They are typically damp or saturated in their lower extents, and their leaves do not exhibit significant internal water transport and have no vascular system (Rydin et al. 2006, Rydin \& Jeglum, 2006; Van Breemen 1995). Due to the lateral packing of the assemblages, only the top few centimetres of Sphagnum mats receive enough light to photosynthesise (Rydin \& Jeglum, 2006). This photosynthesising surface section is called the capitulum. Different Sphagnum species show varying degrees of environmental tolerances and responses, and favour particular microenvironments of topography and wetness. Nevertheless, Sphagnum species show similar forms of reactions to variations in environmental drivers (Johnson et

10 al. 2015).

\subsection{Leaf anatomy and air-gas exchange}

The one-cell-thick Sphagnum leaf has green photosynthesising cells that alternate with larger hyaline cells. The hyaline cells are rigid, transparent, porous, structurally support the plant, and store water through capillarity. The cells die when fully

15 developed within the living plant, but they retain their structural and hydrological functions (Rydin et al. 2006, Rydin \& Jeglum 2006). There is no active control of the rate of the conductance of any substance between the photosynthesising cells in Sphagnum and the atmosphere (Rydin \& Jeglum 2006). These photosynthesising cells are directly in contact with the atmosphere or submerged under water. This is different to vascular plants, which have an opening and closing apertures in the leaf surface that permit atmospheric exchange (e.g. Amthor \& Baldocchi, 2001).

\subsection{Photosynthesis}

There are several different sets of processes within the photosynthesising cells of different types of plants, but each plant type exhibits only one such carbon fixation pathway. The most common is the C3 carbon fixation pathway, which Sphagnum also shows (Loisel, et al. 2009; Price, et al. 1997). $R_{p}$ is equal to the carbon lost to the atmosphere because of energy use by the plant including respiration from leaves, stems and roots. GPP is equal to the carbon that is fixed by photosynthesis as carbohydrate. NPP is the arithmetic difference between GPP and $\mathrm{R}_{\mathrm{p}}$, which results in the physical growth of the plant through the net assimilation of carbon (Amthor \& Baldocchi, 2001; Begon, et al. 2005). 
https://doi.org/10.5194/gmd-2019-51

Preprint. Discussion started: 9 July 2019

(c) Author(s) 2019. CC BY 4.0 License.

(c) (i)

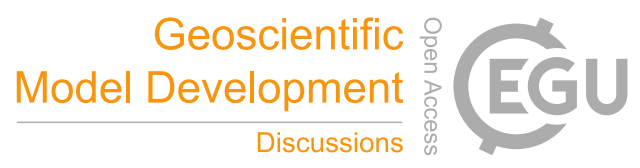

\subsection{Water transport, storage and stress}

Sphagnum plants store water within densely packed stems and leaves, incorporating hyaline cells. The volume stored varies between species (Rydin \& Jeglum 2006). Capillarity enables vertical water transport to occur up the exterior of the stem from the underlying peat, including along deeper dead Sphagnum material (Hayward and Clymo 1982; Rydin \& Jeglum 2006; Van

5 Breemen 1995). There is very little internal vertical water transport within the stems. The assemblages also intercept and absorb water from direct precipitation (Hayward and Clymo 1982; Rydin \& Jeglum 2006; Thompson \& Waddington 2008; Van Breemen 1995), while the closed canopy shelters underlying peat from direct sunlight (Bu et al. 2013; Charman 2002). Sphagnum is desiccation-tolerant, and it suspends its metabolism until wet periods return after which it is quick to recover after drought (Hájek \& Beckett 2008).

10

\subsection{Model components}

Given the above information, we take as a template the carbon exchange equations of TRIFFID and modify them according to specific characteristics of Sphagnum. There are six processes and mathematical process descriptions, in Tables $1 \& 2$. The new model does not explicitly accommodate water storage, transpiration, desiccation-tolerance or variable Sphagnum canopy

$15 \mathrm{CO}_{2}$ uptake and release related to microform position (Wania et al. 2009b). These would require new process understanding and datasets and so they have not been addressed in this version of the TRIFFID Sphagnum PFT model. However, there are 11 important changes to the parameters of the model. Seven parameters were developed using published field and laboratory studies (Table 3), and four used as shaping parameters (Table 4). The following paragraphs describe this parameter development.

20

The new PFT model simulates photosynthesis of a Sphagnum assemblage, which is not simply scaled up individual-behaviour. This is shown in a new empirical water-uptake equation (the right-hand-column for point 1 in Table 2) which simulates the assemblage-water-uptake mechanism (as described in section 2.4). It is based on a similar mechanism for vertically distributed vascular roots in existing TRIFFID vascular PFTs (Cox et al 1998). Cox et al. (1998) found that this has the advantage of programmatic simplicity, employing fewer variables than explicit simulation of water-uptake, whilst still giving a good model fit. This approach directly utilises the unitless volumetric water content of the photosynthesising Sphagnum capitulum as the desiccation-stress factor. The specific desiccation stress factor for the new Sphagnum PFT model was based on field observations derived from Strack et al. (2009) who plotted an empirical function of capitulum water content against the watertable position (WTP) for Sphagnum assemblages and who also found a strong linear relationship between surface volumetric moisture content and assemblage production. Murray et al. (1989) and Riutta et al. (2007), studying bog ecosystems in the foothills of the Philip Smith Mountains, Alaska, and the Lakkasuo bog in southern Finland, respectively, recognised that the maximum Sphagnum photosynthetic production value occurs when the water table is just below the ground surface. A fixed 
https://doi.org/10.5194/gmd-2019-51

Preprint. Discussion started: 9 July 2019

(c) Author(s) 2019. CC BY 4.0 License.

(c) (i)

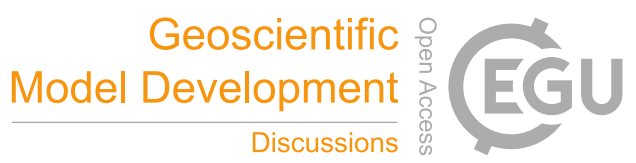

maximum value was therefore used to reproduce this, when the WTP is less than $10 \mathrm{~cm}$ below the ground surface, incorporated as a limit in the Sphagnum equation shown on the right-hand-column for point 1 in Table 2. This new Sphagnum equation provides an overall non-vascular desiccation-stress function, which replaces Cox et al's (1998) vascular desiccation-stress function on the left column of point 1 in Table 2. For leaf air-gas exchange, where a simple scaled-up 'big leaf' approach is

5 used, a fixed value for leaf conductance has been applied in the new Sphagnum PFT model, replacing the variable stomatal conductance used in the TRIFFID vascular PFT model (point 2 in Table 2). This approach is in place of Williams \& Flanagan's (1998) explicit simulation of varying Sphagnum leaf conductance, abstracting away from their higher level of detail in favour of reduced model-complexity (for example dead Sphagnum matter capillarity at the top of the soil column is not incorporated in any DGVMs yet). This follows similar successful approaches in Cox et al. (1998) for vascular plants, and Wania et al.

10 (2009b) and Yurova et al (2007) for Sphagnum growth in the LPJ model.

The equations that simulate photosynthesis and respiration processes that occur within cells, which are unchanged by assemblage-behaviour, are in points 3 and 4 in Table 2. To simulate the photosynthesis biochemical pathway in the new Sphagnum model, the existing C3 carbon fixation function within the TRIFFID vascular PFT sub-model was used to form the

15 basic model. GPP for vascular PFTs is simulated in TRIFFID, as in many other DGVMs, as a function of the minimum of three limiting rates to fix carbon within the photosynthesising cells of a leaf (Clark et al. 2011). These are the light limited rate $\mathrm{GPP}_{1}$, the Rubisco-limited rate, $\mathrm{GPP}_{\mathrm{r}}$, and the rate of transport of photosynthetic products by the plant, $\mathrm{GPP}_{\mathrm{e}}$, which are simulated using the equations on the left-hand column for point 3 in Table 2. In the new Sphagnum model, the conductance between the atmosphere and Sphagnum's photosynthesising tissues is a fixed value representing permanent exposure of the tissues to the atmosphere, resulting in a similar approach to Druel et al. (2017) and Dimitrov et al. (2011) to simulating nonvascular plants' leaf-conductance. The solutions for internal leaf partial pressure ( $c_{r i}$ and $c_{l i}$ respectively) as functions of the photosynthesising processes in the leaf and atmospheric pressure are then solutions of the quadratic equation given on the right-hand column for point 3 in Table 2, thus giving solutions for $\mathrm{GPP}_{\mathrm{r}}$ and $\mathrm{GPP}_{1}$ by substitution. A smoothed minimum value to simulate overall GPP (using the existing TRIFFID smoothing function in simple form on the left-hand column in point 3 of

25 Table 2, and in detailed form in Appendix A) is then calculated from these two values (and the unaltered photosynthetic product transport-limited GPPe). The plant respiration equations (point 4 in Table 2) are unchanged, but the parameters saw significant changes, see sub-section 2.6.

The gas assimilation-inflow continuity equation and surface energy balance equation (respectively points 5 and 6 in Table 2) 30 are unchanged as these describe simple physics that should be the same between non-vascular Sphagnum and vascular plants.

The new Sphagnum PFT model requires changed parameters because Sphagnum has different physical dimensions to the other PFTs already represented in TRIFFID. As a result, there were 11 changes to PFT parameters needed in the new TRIFFID Sphagnum PFT model (Tables 3 and 4). Of the physiology parameters (Table 3), three are parameters for Sphagnum respiration 
https://doi.org/10.5194/gmd-2019-51

Preprint. Discussion started: 9 July 2019

(c) Author(s) 2019. CC BY 4.0 License.

(c) (i)

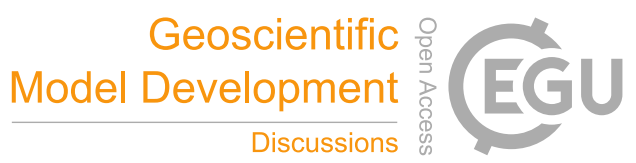

taken from observation-based parameters tested in LPJ-GUESS (N10, $\mathrm{T}_{\text {upp }}, \mathrm{T}_{\text {low }}$ ) while four have had their values established from existing field and laboratory literature on Sphagnum (tleaf_of, infil_f, catch0, Canht_ft). We could not find precise data to constrain the parameters LAI, fd and rg (Table 4) so they were used to shape the output respiration function to the output field data. For example, Yurova et al. (2007) and Bond-Lamberty \& Gower (2007) give rough ranges for these parameters.

5 Appendix B provides the detailed steps taken to set the shaping parameters, which resulted in an initial calibrated model whose outputs are in section 3 . 
https://doi.org/10.5194/gmd-2019-51

Preprint. Discussion started: 9 July 2019

(c) Author(s) 2019. CC BY 4.0 License.

Table 2. Processes and mathematical descriptions of carbon exchange plant growth in C3 PFTs in TRIFFID and the modifications made to them according to the specifics of Sphagnum for the new Sphagnum PFT model.

\section{TRIFFID - C3 vascular plant}

(1) Carbon gain of plant - mass balance

$$
\begin{aligned}
& \boldsymbol{A}=\left(\boldsymbol{G P P}-\boldsymbol{R}_{\boldsymbol{d}}\right) \boldsymbol{\beta} \\
& \boldsymbol{\beta}_{\text {vascular }}=\sum\left\{\begin{array}{cl}
\mathbf{1}, & \boldsymbol{\theta}>\boldsymbol{\theta}_{\boldsymbol{c}} \\
\frac{\boldsymbol{\theta}-\boldsymbol{\theta}_{w}}{\boldsymbol{\theta}_{c}-\boldsymbol{\theta}_{w}}, & \boldsymbol{\theta}_{w}<\boldsymbol{\theta} \leq \boldsymbol{\theta}_{c} \\
\mathbf{0}, & \boldsymbol{\theta}>\boldsymbol{\theta}_{w}
\end{array}\right\}
\end{aligned}
$$

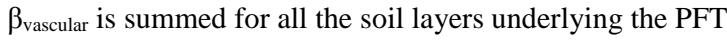

\section{(2) Stomatal conductance}

$$
g_{s}=\frac{\alpha A}{\left(c_{a t m}-\Gamma\right)\left(1+\frac{D}{D_{0}}\right)}
$$

'Simplified Leuning model' - the Leuning (1995) model of stomatal conductance in a vascular plant, was simplified by Cox et al. (1998) by setting optimal minimum canopy conductance to zero.

\section{(3) Photosynthesis machine}

$$
\begin{aligned}
& G P P \approx \min \left(G P P_{r}, G P P_{l}, G P P_{e}\right) \\
& G P P_{r}=V_{m}\left(\frac{c_{i}-\Gamma}{c_{i}+K_{c}\left(1+\mathbf{O}_{a} / K_{0}\right)}\right) \\
& G P P_{l}=0.08(1-\omega) I_{p a r}\left(\frac{c_{i}-\Gamma}{c_{i}+2 \Gamma}\right) \\
& G P P_{e}=0.5 V_{m} \\
& \Gamma=\frac{o_{a}}{2 \tau} \\
& \tau=2600 f_{T}(0.57)
\end{aligned}
$$

Sphagnum (see Appendix A for derivations)

Has the following changes:

$$
\beta_{\text {Sphagnum }}=\left\{\begin{array}{cl}
1, & W T P>-0.1 m \\
e^{\left(\frac{0.1+W T P}{0.16}\right)}, & W T P \leq-0.1 m
\end{array}\right\}
$$

Has the following changes:

$$
g_{s}=1.6 * 0.0237 * 0.07 m s^{-1}
$$

Has the following changes:

$$
\begin{aligned}
& G P P_{r}=V_{m}\left(\frac{c_{r i}-\Gamma}{c_{r i}+K_{c}\left(1+\mathbf{0}_{a} / K_{0}\right)}\right) \\
& G P P_{l}=0.08(1-\omega) I_{p a r}\left(\frac{c_{l i}-\Gamma}{c_{l i}+2 \Gamma}\right) \\
& c_{r i}, c_{l i}=\frac{-B B+\sqrt{B B^{2}-4 A A C C}}{2 A A} \\
& A A_{r}=\frac{G}{V_{m}}, A A_{l}=\frac{G}{I} B B_{r}=\frac{G}{V_{m}}\left(K-c_{a t m}\right)-R_{d}+1
\end{aligned}
$$


https://doi.org/10.5194/gmd-2019-51

Preprint. Discussion started: 9 July 2019

(c) Author(s) 2019. CC BY 4.0 License.

$$
f_{T}\left(T_{\mathrm{c}}\right)=q_{10 \_ \text {leaf }}^{0.1\left(T_{c}-25\right)}
$$

\section{(4) Respiration}

$$
R_{p}=r_{g}\left(\Pi_{G}-R_{p m}\right)+R_{p m}
$$

$($ plant respiration $=$ growth respiration + maintenance respiration $)$

$$
R_{p m}=0.012 \cdot R_{d c}\left(\beta+\frac{N_{r}+N_{s}}{N_{l}}\right)
$$

(maintenance respiration)

$$
\begin{aligned}
& R_{d}=f_{d} \cdot V_{m} \\
& R_{d c}=\sum\left(R_{d}\right)
\end{aligned}
$$

(canopy dark respiration)

\section{(5) Continuity equation}

Assimilation $=$ inflow

$$
A=\frac{g_{s}}{1.6 \bar{R} T_{*}}\left(c_{a t m}-c_{i}\right)
$$

(6) Surface energy balance

$$
R_{S}=S W_{N}+L W_{\downarrow}-\sigma T *^{4}-H-L E-G_{0}
$$

Parameter names in this table:

$$
\text { A - net leaf photosynthesis }\left(\mathrm{mol} \mathrm{CO} \mathrm{Cm}^{-2} \mathrm{~s}^{-1}\right)
$$

$$
\begin{gathered}
B B_{l}=\frac{G}{I}\left(2 \Gamma-c_{a t m}\right)-R_{d}+1 \\
C C_{r}=-\left(\frac{G}{V_{m}} K c_{a t m}+K R_{d}+\Gamma\right) \\
C C_{l}=-\left(\frac{G}{I} 2 \Gamma c_{a t m}+2 \Gamma R_{d}+\Gamma\right)
\end{gathered}
$$

where the following simplifying terms are used:

$$
G=\frac{g_{s}}{1.6 \bar{R} T^{*} \beta}, \quad I=0.08(1-\omega) I_{p a r}, \quad K=K_{c}\left(1+\frac{0_{a}}{K_{0}}\right)
$$

Equations unchanged, new parameters taken from tested Sphagnum parameters in LPJ-GUESS/WHY which in turn were originally based on field data (see appendix B).

Unchanged

Unchanged 
$\mathrm{AA}, \mathrm{BB}, \mathrm{CC}$ - quadratic equation parameters

$\mathrm{AA}_{\mathrm{r}}, \mathrm{BB}_{\mathrm{r}}, \mathrm{CC}_{\mathrm{r}}$ - quadratic equation parameters for case of Rubisco-limitation of GPP

$\mathrm{AA}_{1}, \mathrm{BB}_{1}, \mathrm{CC}_{1}$ - quadratic equation parameters for case of light-limitation of GPP

$\mathrm{c}_{\text {atm }}$ - atmospheric $\mathrm{CO}_{2}$ partial pressure $(\mathrm{Pa})$

$c_{i}$ - internal leaf $\mathrm{CO}_{2}$ partial pressure $(\mathrm{Pa})$

$\mathrm{c}_{\mathrm{ri}}$ - Rubisco-limited internal leaf $\mathrm{CO}_{2}$ partial pressure $(\mathrm{Pa})$

$\mathrm{c}_{\mathrm{li}}$ - light-limited internal leaf $\mathrm{CO}_{2}$ partial pressure $(\mathrm{Pa})$

D - Humidity deficit at the leaf surface $\left(\mathrm{g} \mathrm{kg}^{-1}\right)$

$\mathrm{D}_{0}$ - Leaf surface humidity deficit parameter for the 'Leuning' closure $\left(\mathrm{g} \mathrm{kg}^{-1}\right)$

$\mathrm{f}_{\mathrm{d}}$ - the dark respiration scaling factor

fT - the standard Q10 temperature dependence

$\mathrm{g}_{\mathrm{s}}$ - leaf surface conductance (stomatal conductance in vascular plants) $\left(\mathrm{ms}^{-1}\right)$

G, I, K - terms to simplify the layout of equations in the Sphagnum photosynthesis machine

GPP - leaf Gross Primary Production $\left(\mathrm{mol} \mathrm{CO}_{2} \mathrm{~m}^{-2} \mathrm{~s}^{-1}\right)$

$\mathrm{GPP}_{\mathrm{e}}-\mathrm{GPP}$ rate limited by transport of photosynthetic products by the plant $\left(\mathrm{mol} \mathrm{CO}_{2} \mathrm{~m}^{-2} \mathrm{~s}^{-1}\right)$

$\mathrm{GPP}_{1}$ - light limited rate of GPP $\left(\mathrm{mol} \mathrm{CO} \mathrm{m}^{-2} \mathrm{~s}^{-1}\right)$

$\mathrm{GPP}_{\mathrm{r}}-$ Rubisco-limited rate of GPP $\left(\mathrm{mol} \mathrm{CO}_{2} \mathrm{~m}^{-2} \mathrm{~s}^{-1}\right)$

$\mathrm{G}_{0}$ - heat flux into the ground (see Best et al. (2011) for detail inside this term) $\left(\mathrm{Wm}^{-2}\right.$ )

$\mathrm{H}$ - sensible heat flux $\left(\mathrm{Wm}^{-2}\right)$

$\mathrm{I}_{\text {par }}$ - incident photosynthetically active radiation (mol photons $\mathrm{m}^{-2} \mathrm{~s}^{-1}$ )

$\mathrm{K}_{\mathrm{c}}, \mathrm{K}_{0}$ - Michaelis Menten parameters for $\mathrm{CO}_{2}$ and $\mathrm{O}_{2}(\mathrm{~Pa})$ (see Clark et al. (2011))

$\mathrm{LE}$ - heat flux due to evapotranspiration (latent heat of vaporisation, $\mathrm{L} x$ moisture flux, E) $\left(\mathrm{Wm}^{-2}\right)$

$\mathrm{LW}_{\downarrow}$ - incoming longwave radiation $\left(\mathrm{Wm}^{-2}\right)$

$\mathrm{N}_{1}$ - nitrogen content of leaf portion of plant $\left(\mathrm{mol} \mathrm{CO}_{2} \mathrm{~m}^{-2} \mathrm{~s}^{-1}\right)$

$\mathrm{N}_{\mathrm{r}}$ - nitrogen content of root portion of plant $\left(\mathrm{mol} \mathrm{CO} \mathrm{Cm}^{-2} \mathrm{~s}^{-1}\right)$

$\mathrm{N}_{\mathrm{s}}$ - nitrogen content of stem portion of plant $\left(\mathrm{mol} \mathrm{CO}_{2} \mathrm{~m}^{-2} \mathrm{~s}^{-1}\right)$

$\mathrm{O}_{\mathrm{a}}$ - partial pressure of atmospheric oxygen $(\mathrm{Pa})$ 
https://doi.org/10.5194/gmd-2019-51

Preprint. Discussion started: 9 July 2019

(c) Author(s) 2019. CC BY 4.0 License.

Q10_leaf - Q10 temperature dependence coefficient

$r_{g}-$ growth respiration coefficient

$\mathrm{R}_{\mathrm{pm}}$ - plant maintenance respiration $\left(\mathrm{kgC} \mathrm{m}^{-2} \mathrm{~s}^{-1}\right)$

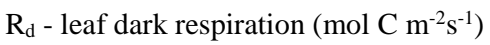

$\mathrm{R}_{\mathrm{p}}$ - plant respiration $\left(\mathrm{kg} \mathrm{C} \mathrm{m}^{-2} \mathrm{~s}^{-1}\right)$

$\mathrm{R}_{\mathrm{S}}$ - surface energy balance $\left(\mathrm{Wm}^{-2}\right)$

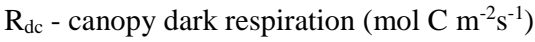

$\mathrm{SW}_{\mathrm{N}}$ - balance of shortwave radiation $\left(\mathrm{Wm}^{-2}\right)$

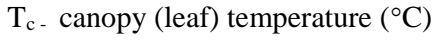

$\mathrm{T} *$ - the leaf surface temperature $(\mathrm{K})$

$\mathrm{V}_{\mathrm{m}}$ - temperature-dependant maximum rate of carboxylation of the Rubisco enzyme $\left(\mathrm{CO}_{2} \mathrm{~m}^{-2} \mathrm{~s}^{-1}\right)$

WTP - water table position (m)

$\alpha$ - Quantum efficiency [mol $\mathrm{CO}_{2}$ (mol PAR, photons) $)^{-1}$ ]

$\beta$ - desiccation stress factor, unitless $(0 \leq \beta \leq 1)$

$\Pi_{\mathrm{G}}-\mathrm{PFT}$-canopy GPP rate $\left(\mathrm{kgC} \mathrm{m}^{-2} \mathrm{~s}^{-1}\right)$

$\theta$ - mean soil water concentration in the root zone

$\theta_{\mathrm{c}}, \theta_{\mathrm{w}}$ - vascular PFT-specific critical and wilting soil moisture concentrations respectively

$\sigma$ - Stefan Boltzmann constant $\left(\mathrm{Wm}^{-2} \mathrm{~K}^{-4}\right)$

$\tau$ - Rubisco specificity for $\mathrm{CO}_{2}$ relative to $\mathrm{O}_{2}$

$\Gamma-\mathrm{CO}_{2}$ photorespiration compensation point $(\mathrm{Pa})$

$\omega$ - the leaf scattering coefficient for PAR 
https://doi.org/10.5194/gmd-2019-51

Preprint. Discussion started: 9 July 2019

(c) Author(s) 2019. CC BY 4.0 License.

Table 3. TRIFFID PFT constrained physiology parameters changed for the new Sphagnum PFT model.

\begin{tabular}{|c|c|c|c|}
\hline Function & Symbol & Value & Description / references \\
\hline Canopy Height & Canht_ft & $0.03 \mathrm{~m}$ & Height of leaves above ground (Smolders, et al. 2001) \\
\hline $\begin{array}{l}\text { Minimum canopy } \\
\text { capacity }\end{array}$ & catch0 & $0.25 \mathrm{~kg} \mathrm{~m}^{-2}$ & Bond-Lamberty \& Gower (2007) \\
\hline $\begin{array}{l}\text { Infiltration enhancement } \\
\text { factor. }\end{array}$ & infil_f & 1.0 & $\begin{array}{l}\text { Reduced compared to grasses (2.0) reflecting lower } \\
\text { hydraulic conductivity }\end{array}$ \\
\hline $\begin{array}{l}\text { Top leaf nitrogen } \\
\text { concentration }\end{array}$ & $\mathrm{N} 10$ & $0.02 \mathrm{~kg} \mathrm{~N} / \mathrm{kg} \mathrm{C}$ & $\begin{array}{l}\text { Wania, et al. (2009b) (Wania, 2007), in approximate } \\
\text { agreement with (Rice 2000) and Aerts et al (2009) }\end{array}$ \\
\hline $\begin{array}{l}\text { Temperature below } \\
\text { which leaves are dropped }\end{array}$ & tleaf_of & 0 Kelvin & Representing no lower limit \\
\hline $\begin{array}{l}\text { Lower temperature for } \\
\text { photosynthesis }\end{array}$ & Tlow & 5.0 Celsius & Gerdol, et al. (1998); Wania, et al. (2009b) \\
\hline $\begin{array}{l}\text { Upper temperature for } \\
\text { photosynthesis }\end{array}$ & Tupp & 36.0 Celsius & Gerdol, et al. (1998); Wania, et al. (2009b) \\
\hline
\end{tabular}


https://doi.org/10.5194/gmd-2019-51

Preprint. Discussion started: 9 July 2019

(C) Author(s) 2019. CC BY 4.0 License.

Table 4. TRIFFID PFT physiology shaping parameters for the new Sphagnum PFT model, compared with equivalent parameters in LPJGUESS Sphagnum PFT.

\begin{tabular}{|c|c|c|c|}
\hline \multirow[t]{2}{*}{ Function } & \multirow[t]{2}{*}{ Symbol } & \multicolumn{2}{|l|}{ Value } \\
\hline & & LPJ-GUESS & TRIFFID \\
\hline $\begin{array}{l}\text { Dark Respiration Scaling } \\
\text { Factor }\end{array}$ & $f_{d}$ & 0.03 & 0.03 \\
\hline $\begin{array}{ll}\text { Growth } & \text { Respiration } \\
\text { Coefficient } & \end{array}$ & $r_{g}$ & 0.5 & 0.1 \\
\hline $\begin{array}{l}\text { Non-Photosynthetic Tissue } \\
\text { Respiration }\end{array}$ & $\mathrm{r}_{\mathrm{m}}$ & 2.0 & Not used \\
\hline Leaf Area Index & LAI & Not used & $\begin{array}{l}\text { 3, hummock/bog species } \\
\text { 1, lawn/fen species }\end{array}$ \\
\hline
\end{tabular}


https://doi.org/10.5194/gmd-2019-51

Preprint. Discussion started: 9 July 2019

(c) Author(s) 2019. CC BY 4.0 License.

\subsection{Model Calibration}

Table 5. Literature sources of quantified Sphagnum respiration and photosynthesis functions.

\begin{tabular}{|c|c|c|c|}
\hline Reference & $\begin{array}{l}\text { Model Functions Adopted in the new Sphagnum } \\
\text { PFT model } \\
\text { [Functions used for output comparisons] }\end{array}$ & $\begin{array}{l}\text { Sphagnum } \\
\text { species quantified }\end{array}$ & $\begin{array}{l}\text { Season when } \\
\text { measurements } \\
\text { taken }\end{array}$ \\
\hline Aerts et al (2009) & Leaf nitrogen concentration & S Fuscum & Summer \\
\hline $\begin{array}{l}\text { Hayward \& Clymo } \\
\text { (1982) }\end{array}$ & $\begin{array}{l}\text { Capitulum volumetric water content against WTP, } \\
\text { similar shaped function to Strack et al. (2009) } \\
\text { (below) }\end{array}$ & $\begin{array}{l}\text { S. Capillifolium } \\
\text { S. Papillosum }\end{array}$ & Not given \\
\hline $\begin{array}{l}\text { Murray et al. } \\
\text { (1989) }\end{array}$ & $\begin{array}{l}\text { Photosynthetic maximum at near surface water } \\
\text { table, agrees with Riutta et al.(2007) (below) }\end{array}$ & $\begin{array}{l}\text { synthesised } \\
\text { studies } \\
\text { of many arctic } \\
\text { species }\end{array}$ & Summer \\
\hline Rice (2000) & Leaf nitrogen concentration & $\begin{array}{l}\text { S. Recervum } \\
\text { S. Palustre } \\
\text { S. Tenerum }\end{array}$ & $\begin{array}{l}\text { Spring } \\
\text { summer }\end{array}$ \\
\hline Riutta et al. (2007) & $\begin{array}{l}\text { Photosynthetic maximum at near surface water } \\
\text { table, but photosynthetic and respiration } \\
\text { responses are otherwise approximately flat } \\
\text { against WTP }\end{array}$ & $\begin{array}{l}\text { S. Papillosum } \\
\text { S. Fallax } \\
\text { S. Flexuosum }\end{array}$ & $\begin{array}{l}\text { 'Growing } \\
\text { season' }\end{array}$ \\
\hline Strack et al. (2009) & $\begin{array}{l}\text { [NPP against WTP, temperature and PAR] } \\
\text { Capitulum volumetric water content against } \\
\text { water table position, after first order correction } \\
\text { for presence of vascular vegetation }\end{array}$ & S. Rubellum & $\begin{array}{l}\text { Very late spring, } \\
\text { summer }\end{array}$ \\
\hline $\begin{array}{l}\text { Williams } \quad \& \\
\text { Flanagan (1998) }\end{array}$ & $\begin{array}{l}\text { [NPP against WTP] } \\
\text { Maximum leaf } \mathrm{CO}_{2} \text { conductance } \\
\text { [Cell dark respiration and } \mathrm{Vm}]\end{array}$ & $\begin{array}{l}\text { S. Rubellum } \\
\text { S. Tenellum } \\
\text { S. Capillifolium } \\
\text { S. Fuscum }\end{array}$ & Summer \\
\hline
\end{tabular}


https://doi.org/10.5194/gmd-2019-51

Preprint. Discussion started: 9 July 2019

(c) Author(s) 2019. CC BY 4.0 License.

(c) (i)

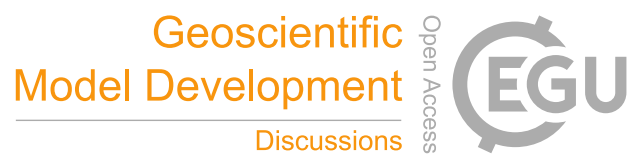

We could only find one set of data that was useful for general model calibration (Table 5 - Strack et al. 2009) and two for validation (Table 5 - Riutta et al. 2007; Williams \& Flanagan 1998). The remaining data sets listed in Table 5 either gave very similar data to these three sources, or individual parameters for the model. Strack et al (2009) presented GPP and $\mathrm{R}_{\mathrm{p}}$ field-data

5 from a Sphagnum-dominated bog ecosystem (nutrient-poor peatland with a shallow to deep water-table) in late spring and summer. Having GPP and $\mathrm{R}_{\mathrm{p}}$ disaggregated was very useful for calibrating our detailed Sphagnum model, and as far as we are aware, these data are the only such published data. Strack et al (2009) studied a mixed ecosystem with at least 90\% Sphagnum cover, so, unfortunately, the field-data did not represent isolated Sphagnum behaviour. However, we found a first-order correction, based on data from Riutta et al (2007), who showed that peatland vascular vegetation NPP (which is GPP-R $\mathrm{R}_{\mathrm{p}}$ )

10 against WTP is approximately horizontal, or uncorrelated. Additionally, Riutta's Sphagnum GPP data asymptotically approaches zero for deep water tables, which leads to desiccation of the capitulum, a theory supported by observations from Bewley et al. (1978), Hájek \& Beckett (2008) and Hayward \& Clymo (1982). Therefore, a first order correction was applied by simply subtracting a fixed positive offset (assumed to represent the influence of vascular plants) from the $\mathrm{R}_{\mathrm{p}}$ and GPP data of Strack et al (2009) so it has $\mathrm{R}_{\mathrm{p}}$ and GPP approaching zero for very low WTP values. The resultant NPP data was in this way 15 transformed to give the calibration data shown in Figure 1.

Our model was calibrated to reproduce the transformed GPP, NPP and $\mathrm{R}_{\mathrm{p}}$ data of Strack et al (2009). We used fixed environmental model-inputs (PAR, temperature and WTP), running the model like a controlled laboratory without varying climate inputs. $r_{g}$ (growth respiration coefficient - see Table 4) was adjusted to set the $R_{p}$ curve in the correct position. The

20 NPP curve merely is the algebraic sum of these two curves. This parameter-fitting exercise is described fully in Appendix B. The outcomes are in Figure 1. 


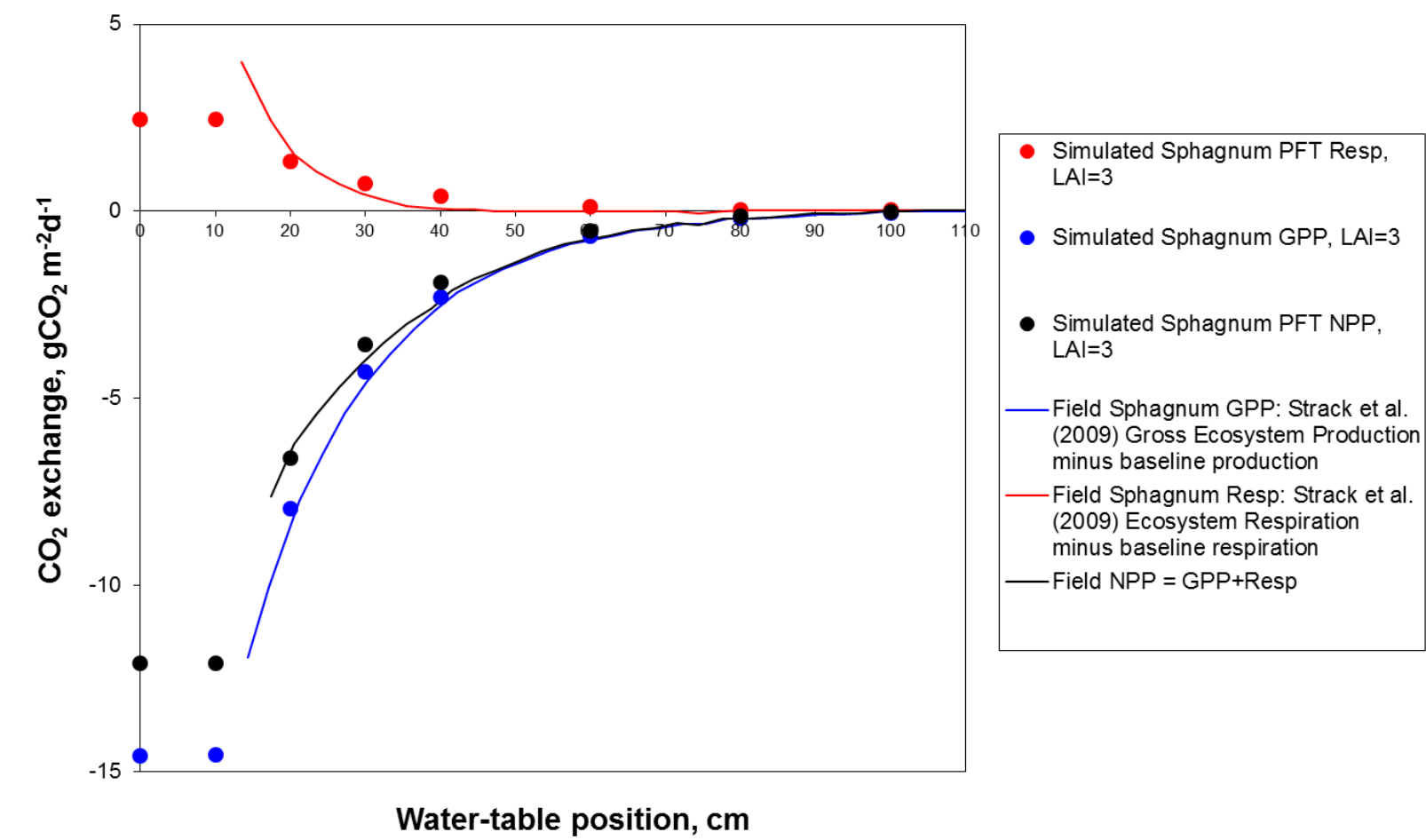

Figure 1. Model outputs of respiration, GPP, and NPP against WTP, calibrated with field measurements from a Sphagnumdominated peatland constructed using data derived from Strack et al (2009).

\section{Results}

5 The calibrated Sphagnum PFT model was tested against the limited data available from Riutta et al (2007) and Williams \& Flanagan (1998) and gave good visual matches against these quite complex measured functions of varying ecosystem productivity and respiration. The degree of fit was not measured quantitatively, because getting the shape of all the various output functions of the model right was a much higher priority than the accuracy of fit, and the test-data is very limited. The model reproduced the shape of the seven different curves in both calibration and test datasets with a limited amount of fine tuning.

Riutta et al (2007) measured GPP of mixed peatland vegetation in a nutrient-poor fen (peatland with a shallow water-table fed by lateral inflows). They isolated Sphagnum GPP but not $\mathrm{R}_{\mathrm{p}}$ or NPP, at a field plot during the 
growing season. This was not a time series such as is common in ecosystem $\mathrm{CO}_{2}$ eddy-covariance measurements, but rather as isolated functions of GPP against PAR, temperature and WTP. Our model was, therefore, run using fixed environmental model-inputs (PAR, temperature and WTP) to reproduce Sphagnum GPP functions against temperature and PAR, to simulate the Riutta data. One change was required to the LAI parameter to accommodate 5 the different Sphagnum species to the earlier calibration data, explained in Appendix B.2. We note that this curvefitting factor may have corrected more than just the LAI differences between Sphagnum-species, which is further addressed in section 4 . The model output is therefore compared to the Riutta test-data in figure 2.

Also, non-desiccation-stressed full daylight canopy dark respiration within the TRIFFID Sphagnum model was 10 between $0.4 \mu \mathrm{mol} \mathrm{m} \mathrm{s}^{-1}$ (LAI=1, fen Sphagnum) and $0.7 \mu \mathrm{mol} \mathrm{m}^{-2} \mathrm{~s}^{-1}\left(\mathrm{LAI}=3\right.$, bog Sphagnum). $\mathrm{V}_{\max }$ is a fixed value in the model of $16 \mu \mathrm{mol} \mathrm{m}^{-2} \mathrm{~s}^{-1}$ from equation A.11, being proportional to the leaf nitrogen content value, $\mathrm{nl}^{\left(\mathrm{kgNm}^{-}\right.}$ ${ }^{2}$ ), which is a fixed value in the model. These values compare well with Williams \& Flanagan's (1998) average daylight summer laboratory measurements of a truncated bog/poor fen Sphagnum sample with an uncertain LAI, giving a value for canopy dark respiration of $1.0 \pm 0.3 \mu \mathrm{mol} \mathrm{m} \mathrm{m}^{-2} \mathrm{~s}^{-1}$ (at one standard deviation) and a value for $\mathrm{V}_{\max }$ 15 of $14.0 \pm 4.0 \mu \mathrm{mol} \mathrm{m} \mathrm{m}^{-2}$.

Thus, using available field or laboratory data, our Sphagnum PTF model visually reproduces the shape of laboratory-derived Sphagnum- $\mathrm{CO}_{2}$ exchange curves, but with some clear residuals of up to about $40 \%$ against WTP and temperature, and up to $+100 \%$ against PAR. The significant amount of detailed work performing the above calibrations and testing is described in Appendices $1 \& 2$. 
https://doi.org/10.5194/gmd-2019-51

Preprint. Discussion started: 9 July 2019

(c) Author(s) 2019. CC BY 4.0 License.
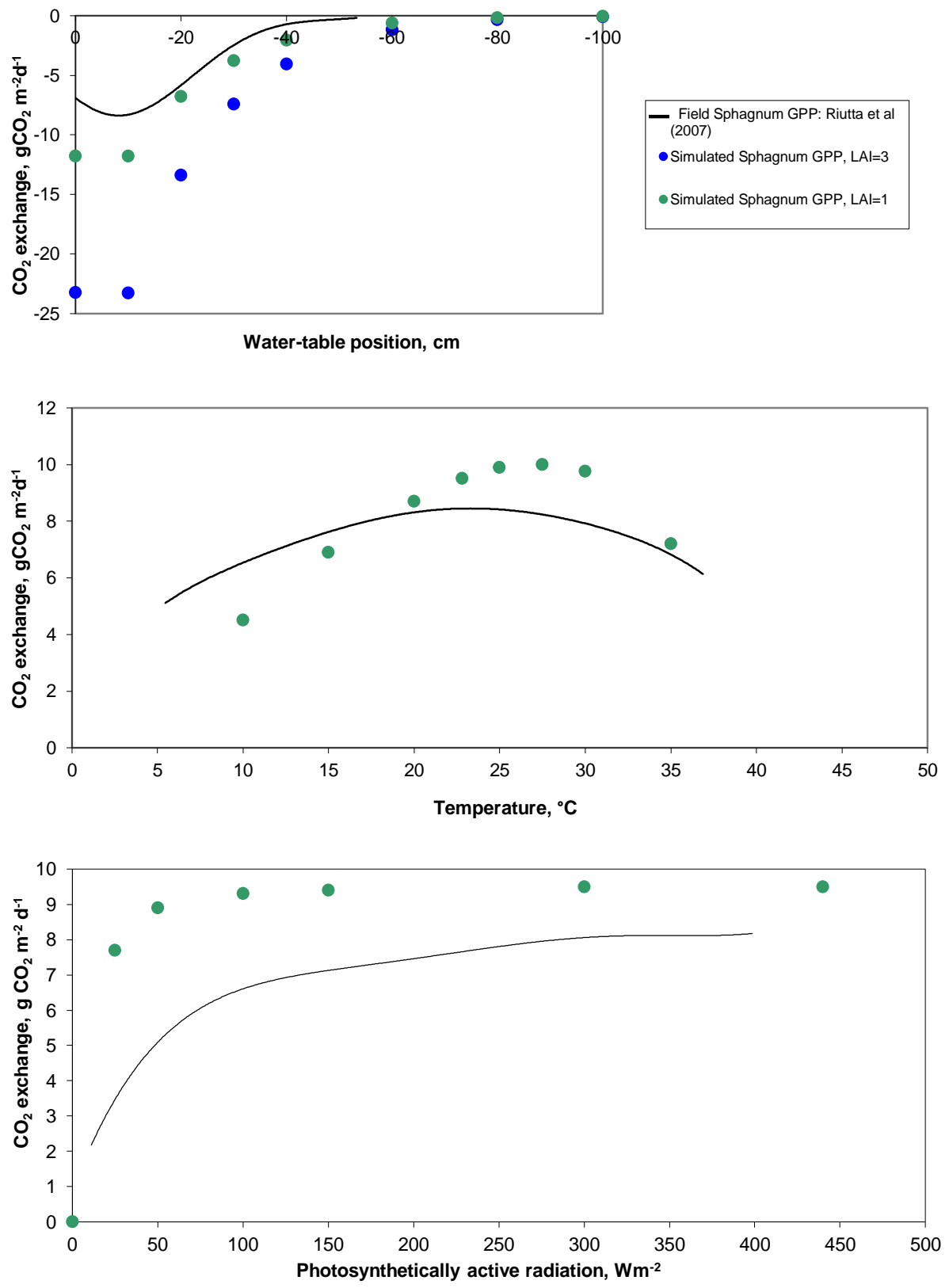

Figure 2. Model outputs of GPP against WTP, temperature, and PAR, compared to field data from a Sphagnum-dominated peatland obtained by Riutta et al (2007). 


\section{Discussion and Conclusions}

A new process-based non-vascular-PFT model has been developed. Sphagnum mosses exhibit characteristic curves of $R_{p}$, GPP and NPP against WTP, PAR and temperature that are very markedly different to vascular plants (see

5 Riutta et al. 2007). The new Sphagnum model reproduced the overall shape of these Sphagnum curves without any calibration. We believe this is the first time any process-based non-vascular plant photosynthesis model has reproduced these distinct curves. The model required only $r_{g}$ adjusting in order to calibrate it to the data from Strack et al (2009). Only a simple adjustment of the LAI parameter, being well supported by the literature to accommodate a different Sphagnum species, allowed our model to reproduce Riutta et al's (2007) GPP curves against WTP and temperature within about $\pm 40 \%$ of the field-measurements. The fit to Riutta's PAR curve was less accurate at between $+20 \%$ and $+100 \%$ residual. We did not attempt any closer fitting here because this was intended to be test data to validate the initial calibration against the Strack data. There is insufficient test data to support statistical analysis of the residuals, with only a small number of features in the test-data curves. However, we also note that no previously published process-based models that we could find of Sphagnum photosynthesis (Druel et al. (2017),

15 Qiu et al. (2018), Wania et al. (2009a, 2009b) and Yurova et al. (2007)) made any comparison to isolated field Sphagnum-NPP data, so our model is a first attempt at a greater level of process-detail together with a direct comparison to this field data. Of course, more field data would be welcome to improve confidence and to help refine the model.

Furthermore the use of LAI and $r_{g}$ as curve-fitting factors may accommodate a broad range of uncertainty elsewhere

20 in the fitting of the model parameters, including, for example, varying photosynthetic efficiency of different Sphagnum species, internal near-surface water storage, transpiration, and varying $\mathrm{CO}_{2}$ transport pathways available through pore-water and the atmosphere to the Sphagnum capitulum (Proctor et al, 1992; Lamers, 1999; Limpens et al 2008). These are little understood and therefore not candidate functions to be included in the Sphagnum PFT model in the foreseeable future.

Improved Sphagnum NPP models offer the possibility of simulating the accumulation of peatland plant litter with varying decomposition recalcitrance values and hydraulic properties (Wania, et al. 2009a), which influence the stability of the peat soil carbon store (Belyea 2009; Frolking et al. 2001). These two points are consistent with the observation of complex feedbacks between plant physiology and soil moisture (Bevan 2012) and Laurent et al.'s 
(2004) view that, in order to improve the accuracy of existing vegetation carbon cycling simulations, simple climate-correlation (Brovkin et al. 1997; Prentice et al. 1992) may be enhanced by the inclusion of non-climate factors including plant-soil feedbacks. Additional parameters to be integrated within the model could be, for example, nutrient content (the nitrogen cycling is already represented in some other bryophyte models, e.g. 5 Euskirchen et al. 2009), intra-annual flood-frequency as already simulated explicitly in LPJ-WHY (Wania, et al. 2009b) and implicitly in JULES (O'Connor et al. 2010), and the influence of small-scale land topography on vegetation assemblage functions at higher scales (Baird et al. 2009; Belyea \& Baird 2006; Sonnentag et al. 2008; Waddington \& Roulet 1996).

10 Additionally, field and laboratory measurements show that Sphagnum $\mathrm{V}_{\max }$ has significant seasonal variation. All of the literature sources used to calibrate the photosynthetic and respiratory function of our model collected their data from Sphagnum samples taken during summer (see Table 5). Hence, the seasonal pattern of Sphagnum photosynthesis cannot be produced by this initial version of the TRIFFID Sphagnum model. Williams \& Flanagan (1998) measured reduced $V_{\max }$ values in spring and autumn, at half the summer value. This can be ascribed to a

15 summer maximum concentration of photosynthesising tissue (Skre \& Oechel, 1981). Leaf nitrogen content is strongly correlated with plant photosynthesising capacity (Woodward 1994). Rice (2000) measured seasonal changes in the capitulum carbon to nitrogen ratio in three Sphagnum species that occupy contrasting niches on a temperate wetland in North Carolina. This showed a clear trend of increasing capitulum nitrogen concentration compared to carbon, which is strongly indicative of nl, leaf nitrogen concentration, between March and September,

20 and suggests that $\mathrm{nl}$ in Sphagnum should follow a seasonal pattern with a maximum value in summer. Therefore, the introduction of seasonally varying $\mathrm{nl}$ in place of the current fixed value in the model, is a candidate for future simulation of seasonal changes to Sphagnum $\mathrm{V}_{\max }$. Furthermore, while the quantum efficiency value in this model has been maintained at the C3 value of 0.08, used in JULES vascular PFTs, Kangas et al (2014) have measured quantum efficiency values for Sphagnum between 0.09 and 0.12 seasonally (with a minimum in July) and across different Sphagnum species, but not correlated with local environment variables.

While the main focus of this paper has been the development of the new TRIFFID Sphagnum PFT model, the model we have produced is also readily suited to simulate true mosses, which play an important role in boreal ecosystems overlying unsaturated soils (Bond-Lamberty et al. 2004; Wieder, et al. 2006, Beringer et al 2001; Lindo 
\& Gonzalez 2010; Street et al. 2013). However, true mosses generally hydrate due to capillarity in their lower portions, distillation from a nocturnal temperature inversion of the underlying soil surface in their upper portions, or direct interception of precipitation (Carleton \& Dunham, 2003; Lindo \& Gonzalez 2010). This would require the replacement of the empirical water-uptake equation (point 1 in table 2) with a function reflecting this different moisture-uptake mechanism, which is a relatively minor modification to the new Sphagnum non-vascular PFT. Precise quantification of this function does not yet appear to have been made empirically or theoretically, and this would be an important next step in enabling the adaptation of the current model to true mosses.

The most important outcome of this study is to have, for the first time, computationally solved the two-way

10 simultaneous function that governs photosynthesis in the non-vascular Sphagnum plant, thus simulating photosynthetic and respiratory functions of Sphagnum, which differ significantly from equivalent vascular vegetation functions, reproducing visually the NPP functions of Sphagnum samples. In other words we have developed, for the first time, a Sphagnum NPP model that resembles the internal function of the actual Sphagnum NPP mechanism, at a higher level of detail than existing PFT models such as those produced by Druel et al.

15 (2017), Qiu et al. (2018), Wania et al. (2009a, 2009b) and Yurova et al. (2007). Our work may therefore also contribute to a general photosynthesis model for Sphagnum beyond the immediate needs of DGVMs. It has been implemented in an existing latest-generation DGVM at a consistent level of detail and computational efficiency with the DGVM, but not coupled with the land-surface-functions of the DVGM such as hydrology and soil development, so it has not been possible to compare outputs to ecosystem eddy-covariance time-series.

20 Nevertheless even as it stands, the new model can be a tool to examine the carbon cycling patterns of Sphagnum under different climates. 


\section{Appendix A. Simulation of net leaf photosynthesis}

\section{A.1 Adaption of TRIFFID's C3 Photosynthesis Function to Sphagnum}

Sphagnum exhibits the C3 carbon fixation photosynthesis pathway (Loisel, et al. 2009; Price, et al. 1997; Proctor et al. 1992). The TRIFFID vascular PFT with C3 carbon fixation has been adapted to replicate the non-vascular

5 Sphagnum photosynthesis function. This involved replacing the stomatal regulation of gas exchange in the model with a fixed leaf conductance value, and removing the ability to extract water from deep in the soil using a vascular root system.

The TRIFFID functions that were adapted to newly simulate Sphagnum physiology are summarised here from Best et al. (2011) and Clark et al. (2011) (equation numbers with asterix). In TRIFFID, net leaf photosynthesis A (mol $\mathrm{CO}_{2} \mathrm{~m}^{-2} \mathrm{~s}^{-1}$ ) is computed using the solution to equations A.1 to A.6. GPP is the gross leaf photosynthesis, $\beta$ is the desiccation stress factor, a unit-less value between 0 and 1 , simulated for vascular plants using equation A.6, where $\Theta$ is the mean soil water concentration in the root zone, and $\Theta_{c}, \Theta_{w}$ are the PFT-specific critical and wilting soil moisture concentrations respectively. Cox et al. (1998) showed that the simple desiccation-stress function in equation A.1 improved the fit of a vascular vegetation model for a minimal number of extra parameters. $R_{d}$ is dark respiration (see section 1), which is a linear function of $\mathrm{V}_{\max }$ and $\mathrm{f}_{\mathrm{T}}$. $\mathrm{c}_{\mathrm{atm}}$ is the atmospheric $\mathrm{CO}_{2}$ partial pressure $(\mathrm{Pa})$, and $\mathrm{c}_{\mathrm{i}}$ are the rubisco- and light-limited potential internal leaf $\mathrm{CO}_{2}$ partial pressures. $\mathrm{O}_{\mathrm{a}}$ is the atmospheric oxygen $\left(\mathrm{O}_{2}\right)$ partial pressure $(\mathrm{Pa})$. $\mathrm{R}$ is the ideal gas constant, $\mathrm{T}^{*}$ is the leaf surface temperature $(\mathrm{K}), \Gamma$ is the $\mathrm{CO}_{2}$ photorespiration compensation point $(\mathrm{Pa})$ where photosynthesis balances respiration. In TRIFFID this is simulated

20 as a function of $\mathrm{O}_{a}$ and the Rubisco specificity of $\mathrm{CO}_{2}$ relative to $\mathrm{O}_{2}, f_{T} f_{T}$, equations A.7 and A.8. $\omega \omega$ is the leaf scattering coefficient for PAR, for which TRIFFID assumes $\omega \omega=0.15$ for C3 plants, and the value 0.08 in equation A.4 represents the quantum efficiency of C3 plants, $\alpha$. Equation A.2 is the $\mathrm{CO}_{2}$ diffusion equation.

For vascular plants exhibiting C3 photosynthesis, TRIFFID solves equations A.2 to A.5 as three simultaneous functions of leaf surface gas conductance (equation A.2), gross photosynthetic rate, GPP, and stomatal closure, which is a function of the leaf humidity deficit - see Table 2 (Cox et al 1998). GPP is calculated using a smoothed minimum of $\mathrm{GPP}_{\mathrm{r}}, \mathrm{GPP}_{1}$, and $\mathrm{GPP}_{\mathrm{e}}$ (equation 1), which are GPP under photosynthetic-enzyme (Rubisco) limitation, light limitation, and photosynthetic-electron-transport limitation respectively, equations A.3 to A.5, 
where Clark et al. (2011) in TRIFFID follows Sellers et al. (1996) and Cox et al. (1999). The three unknowns that are resolved, by the existing TRIFFID vascular PFT function, are $\mathrm{A}, \mathrm{c}_{\mathrm{i}}$, and $\mathrm{g}_{\mathrm{s}}$.

$\boldsymbol{A}=\left(\boldsymbol{G P P}-\boldsymbol{R}_{\boldsymbol{d}}\right) \boldsymbol{\beta}$

$5 \quad A=\frac{g_{s}}{1.6 R T_{*}}\left(c_{a t m}-c_{i}\right)$

$G P P_{r}=V_{m}\left\{\frac{c_{i}-\Gamma}{c_{i}+K_{c}\left(1+0_{a} / K_{0}\right)}\right\}$

$G P P_{l}=0.08(1-\omega) I_{\text {par }}\left\{\frac{c_{i}-\Gamma}{c_{i}+2 \Gamma}\right\}$

$G P P_{e}=0.5 V_{m}$

$\boldsymbol{\beta}_{\text {vascular }}=\left\{\begin{array}{cl}1, & \theta>\boldsymbol{\theta}_{c} \\ \boldsymbol{\theta}-\boldsymbol{\theta}_{w} & \boldsymbol{\theta}_{w}<\boldsymbol{\theta} \leq \boldsymbol{\theta}_{c} \\ \boldsymbol{\theta}_{c}-\boldsymbol{\theta}_{w} & \boldsymbol{\theta}>\boldsymbol{\theta}_{w} \\ 0, & \end{array}\right\}$

$10 \Gamma=\frac{\boldsymbol{o}_{a}}{2 \tau}$

$f_{T}\left(q_{10}\right)=q_{10}^{0.1\left(T_{c}-25\right)}$

$\mathrm{V}_{\mathrm{m}}$ is calculated in equation A.10, and is a function of the lower and upper PFT-temperature production limits,

$15 \mathrm{~T}_{\text {upp }}$ and $\mathrm{T}_{\text {low }}$ and $\mathrm{Q} 10$ temperature dependence, $\mathrm{f}_{\mathrm{T}}$, the non-temperature-dependent rate, $\mathrm{V}_{\max }$, that simulates nitrogen-limitation of $\mathrm{C} 3$ photosynthesis (Clark et al. 2011) and leaf surface temperature, $\mathrm{T}_{\mathrm{c}}$. $\mathrm{V}_{\max }$, equation

A.11 is kept the same for Sphagnum and other C3 plants following the example of Yurova, et al. (2007), and is a linear function of leaf nitrogen concentration, $\mathrm{nl}\left(\mathrm{kgNm}^{-2}\right)$.

$20 \quad v_{m}=\frac{v_{\max } f_{T}(2.0)}{\left(1+e^{0.3\left(T_{c}-T_{u p p}\right)}\right)\left(1+e^{0.3\left(T_{l o w}-T_{c}\right)}\right)}$ 


\section{A.2 Gas Exchange Formulation for Sphagnum PFT}

$\mathrm{g}_{\mathrm{s} \text { Sphagnum }}$ applied to equation A. 2 was set to $1.6 * 0.0237 * 0.07 \mathrm{~ms}^{-1}$ and is unregulated, reflecting constant exposure of the Sphagnum photosynthesising tissues to the atmosphere. The 1.6 is unitless and accounts for differing molecular diffusivity of $\mathrm{CO}_{2}$ and water vapour in air, and $0.07 \mathrm{~mol} \mathrm{~m} \mathrm{~m}^{-2} \mathrm{~s}^{-1}$ is the maximum $\mathrm{CO}_{2}$ conductance measured in Sphagnum by Williams \& Flanagan (1998). The value of $0.0237 \mathrm{~m}^{3} \mathrm{~mol}^{-1}$ is a fixed non-temperaturedependent amount for the molar volume. It is not clear that Williams \& Flanagan's (1998) $\mathrm{CO}_{2}$ conductance in mol $\mathrm{m}^{-2} \mathrm{~s}^{-1}$ within the living Sphagnum tissue would be constant with respect to temperature. Therefore, for simplicity, the molar conversion avoids temperature-dependence. This is in order to avoid adding complexity (adding temperature dependence to the Sphagnum volumetric gas absorption function) which may make the analysis of this initial model difficult. Williams \& Flanagan (1998) ascribed lower values to desiccation-stress, which were not applied in our model because desiccation-stress is simulated independently using the desiccation stress factor, $\beta$, defined for our Sphagnum model in Table 2. This is based on field observations from Strack et al. (2009) (capitulum water content against WTP), Murray et al. (1989) and Riutta et al. (2007) (maximum Sphagnum photosynthetic production value occurs when the water table is just below the ground surface). It is also similar to the approach of

15 Wania et al. (2009b), Yurova et al (2007) for their Sphagnum models. Only two simultaneous functions needed solving to simulate Sphagnum photosynthesis, represented by equations A.2 to A.5, leaving out completely the stomatal conductance term referred to in Table 2. Therefore, we changed the three-way simultaneous function described in appendix A.1 for vascular plants, to a two-way simultaneous function for non-vascular Sphagnum. The two unknown variables are A, and $\mathrm{c}_{\mathrm{i}}$. Combining equations A.1 and A.2 with equations A.3 (rubisco-limited net leaf photosynthesis), and then combining equations A.1 and A.2 with equation A.4 (light-limited net leaf photosynthesis), given that $\mathrm{g}_{\mathrm{s}}$ is now fixed, gives equations A.12 and A.13:

$$
\begin{aligned}
& \mathbf{0}=\frac{\alpha}{V_{m}} c_{r i}^{2}+\left(\frac{\alpha}{V_{m}}\left(K-c_{a t m}\right)-R_{d}+1\right) c_{r i}-\left(\frac{\alpha}{V_{m}} K c_{a t m}+K R_{d}+\Gamma\right) \\
& \mathbf{0}=\frac{\alpha}{\gamma} c_{l i}^{2}+\left(\frac{\alpha}{\gamma}\left(2 \Gamma-c_{a t m}\right)-R_{d}+1\right) c_{l i}-\left(\frac{\alpha}{V_{m}} K c_{a t m}+K R_{d}+\Gamma\right)
\end{aligned}
$$

where $\alpha=\frac{g_{s}}{1.6 R T^{*} \beta}, \gamma=0.08(1-\omega) I_{\text {par }}, K=K_{c}\left(1+\frac{0_{a}}{K_{0}}\right) . \alpha, \gamma$ and $\mathrm{K}$ are terms to simplify equations A.17 and A.18. 
In the new Sphagnum PFT, leaf-surface conductance is fixed and the rate of photosynthesis varies. Therefore, under different limited rates of photosynthesis, we have split $\mathrm{c}_{\mathrm{i}}$ (internal leaf $\mathrm{CO}_{2}$ partial pressure) to distinguish it between $c_{r i}$ (under rubisco-limitation) and $c_{\text {li }}$ (under light-limitation). In the equations for the prior vascular TRIFFID PFT, $c_{i}$ was instead the same value under both limitations. (This does not affect the use of equations 1 and 2 to calculate $g_{s}$ in the new Sphagnum PFT since these equations are not used to calculate $\mathrm{g}_{\mathrm{s}}$, which has a fixed value instead). The quadratic solutions to equations A.12 and A.13 give a positive and a negative value for $\mathrm{c}_{\mathrm{ri}}$ and $c_{\mathrm{li}}$. The positive solutions for $\mathrm{c}_{\mathrm{ri}}$ and $\mathrm{c}_{\mathrm{li}}$ were substituted respectively into equations A.3 and A.4 to give unique values of $\mathrm{GPP}_{\mathrm{r}}$ and $\mathrm{GPP}_{1}$. The question of whether to use the positive or negative quadratic solution was answered in the following way. The standard quadratic solution is:

$10 \quad c_{i}=\frac{-B \pm \sqrt{B^{2}-4 A D}}{2 A}$

Applying equation A.14 to equations A.12 and A.13, where all the additional variables are positive numbers:

$$
A_{r}=\left\{\frac{\alpha}{V_{m}}\right\}, A_{l}=\left\{\frac{\alpha}{\gamma}\right\}
$$

It follows that $A>0$ in both cases.

$B_{r}=\frac{\alpha}{V_{m}}\left(K-c_{a t m}\right)-R_{d}+1, \quad B_{l}=\frac{\alpha}{\gamma}\left(2 \Gamma-c_{a t m}\right)-R_{d}+1$

15 It follows that $B>0$ or $B<0$ are both possible.

$D_{r}=-\left\{\frac{\alpha}{V_{m}} K c_{a t m}+K R_{d}+\Gamma\right\}, \quad D_{l}=-\left\{\frac{\alpha}{\gamma} 2 \Gamma c_{a t m}+2 \Gamma R_{d}+\Gamma\right\}$

It follows that $D<0$, therefore $-4 A D>0$, and $\sqrt{B^{2}-4 A D}>B$. So in order for the quadratic equation to give positive values for $\mathrm{c}_{\mathrm{ri}}$ and $\mathrm{c}_{\mathrm{li}}$, then its solution must take the form of equation A.18.

$20 c_{r i}, c_{l i}=\frac{-B+\sqrt{B^{2}-4 A D}}{2 A}$

The smoothed minimum value for GPP is then calculated using the existing smoothing algorithm in TRIFFID (Clark et al. 2011) from the unique solutions to equations A.3 through A.5. This creates a new version of the photosynthesis process in Table 2 (Foley et al. 1996, Clark et al. 2011) adapted to accommodate the differences in the Sphagnum organism described in section 2. 


\section{Appendix B. Use of Shaping Parameters}

\section{B.1 Simulation of Sphagnum plant respiration}

We compared the equations that simulate respiration in TRIFFID with the equivalent LPJ equations from Yurova et al. (2007), in order to correctly apply the Sphagnum field-derived parameterisations from LPJ's respiration 5 equations to TRIFFID.

In TRIFFID, $R_{p}$ is a function of $R_{d}$, dark leaf respiration, in equations B.1 and B.7, which is simulated explicitly. Dark respiration is the plant respiration that occurs in cell mitochondria as opposed to photosynthesising cell components. The former provides energy for plant function whereas the latter reduces specifically photosynthetic 10 efficiency (Allaby, 2006).

Equations B.1 and B.6 have the same form, simulating $R_{\mathrm{p}}$, in TRIFFID ( $\mathrm{R}_{\mathrm{pT}}$ - units of $\left.\mathrm{kgCm}^{-2} \mathrm{~s}^{-1}\right)$ and LPJ-GUESS $\left(\mathrm{R}_{\mathrm{pLPJ}}\right.$ - units of $\left.\mathrm{kgCm}^{-2} \mathrm{~d}^{-1}\right)$ respectively.

\section{TRIFFID}

$R_{p T}=r_{g T}\left(\Pi_{G T}-R_{p m T}\right)+R_{p m T}$

$\Pi_{G T}=0.012\left(A_{C}+R_{d c} \beta\right)$

$R_{d}=f_{d T} \cdot V_{\max } f_{T}(2.0)$

$\boldsymbol{R}_{\boldsymbol{d c}}=\sum\left(\boldsymbol{R}_{\boldsymbol{d}}\right)$

\section{LPJ-GUESS}

$\boldsymbol{R}_{p L P J}=r_{g L P J}\left(\Pi_{G L P J}-R_{p n o n-p h o t L P J}-R_{p p h o t L P J}\right)+\left(\boldsymbol{R}_{\text {pnon-photLPJ }}+\boldsymbol{R}_{\text {pphotLPJ }}\right)$

$\mathrm{R}_{\mathrm{pmT}}$ is plant maintenance respiration in TRIFFID; this is a function of canopy dark leaf respiration from equation

B.7 . The first right-hand term in equations B.1 and B.6 simulate growth respiration that is proportional to canopy NPP, $\left(\prod_{G}-\mathrm{R}_{\mathrm{pm}}\right)$ in TRIFFID, and ( $\left.\prod_{G}-\mathrm{R}_{\text {pnon-photLPJ }}-\mathrm{R}_{\mathrm{pphotLPJ}}\right)$ in LPJ. $\mathrm{r}_{\mathrm{g}}$ is the growth respiration coefficient, and 
$\prod_{G}$ is PFT-canopy GPP rate $\left(\mathrm{kgC} \mathrm{m}^{-2} \mathrm{~s}^{-1}\right)$. The second right-hand terms simulate maintenance respiration. $\mathrm{R}_{\text {pnon- }}$ phot and $\mathrm{R}_{\text {pphot }}$ in LPJ-GUESS refer to respiration in photosynthetic and non-photosynthetic tissues. $\mathrm{R}_{\mathrm{dc}}$ and $\mathrm{A}_{c}$, in TRIFFID, are canopy dark respiration and canopy net photosynthesis, upscaled from leaf dark respiration, $\mathrm{R}_{\mathrm{d}}$, and net leaf photosynthesis, A, using the 'big-leaf' method (see Clark et al. 2010; Clark et al. 2011; Cox, et al. 1999), 5 in simplified equations B.4 and B.5. We used this method for simplicity and execution-speed; TRIFFID also has more sophisticated and less computationally efficient leaf-area upscaling methods that were not used. $R_{\mathrm{pm}}$ in TRIFFID is an equivalent term to $\left(R_{\text {pnon-phot }}+R_{\text {pphot }}\right)$ in LPJ-GUESS.

TRIFFID

$R_{p m T}=0.012 \cdot R_{d c}\left\{\beta+\frac{N_{r}+N_{s}}{N_{l}}\right\}$

$10 \mathrm{~N}_{\mathrm{l}}$, is the leaf nitrogen content. $\mathrm{N}_{\mathrm{s}}$ and $\mathrm{N}_{\mathrm{r}}$ are the stem and root nitrogen contents. We split Equation B.7 to compare $\mathrm{R}_{\text {pphotT }}$ against $\mathrm{R}_{\text {pphotLPJ. }}$

TRIFFID

$R_{\text {pmT }}=R_{\text {pnon-phot } T}+R_{\text {pphotT }}$

$R_{p p h o t T}=0.0012 \cdot R_{d c} \cdot \beta$

15 LPJ-GUESS

$R_{p p h o t L P J}=f_{d L P J} \cdot V_{\max }$

Whereas in LPJ $\mathrm{R}_{\text {pphotLPJ }}$ is non-temperature dependant (equation B.10), in TRIFFID $\mathrm{R}_{\text {pphotT }}$ has a Q10 temperaturedependence function (equations B.3, B.4, B.8 and B.9), but $\mathrm{f}_{\mathrm{d}}$, the unitless dark respiration scaling factor, in both

20 LPJ and TRIFFID is applied simply to $\mathrm{V}_{\max }$ (equations B.3 (TRIFFID) and B.10 (LPJ), so the value $\mathrm{f}_{\mathrm{dT}}=\mathrm{f}_{\mathrm{dLPJ}}=0.03$ for Sphagnum has been adopted for TRIFFID unchanged from LPJ. 
Respiration within non-photosynthetic tissue again shows a similar form for LPJ-GUESS and TRIFFID.

TRIFFID

$$
R_{\text {pnon-photT }}=0.012 \cdot R_{d c}\left\{\frac{N_{r}+N_{s}}{N_{l}}\right\}
$$

\section{LPJ-GUESS}

$5 \quad R_{\text {pnon-photLPJ }}=r_{m} \cdot k_{r} \cdot g\left(T_{\text {air }}\right)\left\{\frac{M}{c n}\right\}$

In equation B.12 the combination of the shaping parameter $r_{m}, k_{r}$ and $g\left(T_{\text {air }}\right)$ represent a similar term to $R_{d c}$ in TRIFFID. $\mathrm{k}_{\mathrm{r}}\left(\mathrm{day}^{-1}\right)$ is the respiration rate for a $10^{\circ} \mathrm{C}$ baseline, and $\mathrm{g}\left(\mathrm{T}_{\text {air }}\right)$ is a temperature response function (Yurova, et al. 2007). $\mathrm{M}$ is total biomass $\left(\mathrm{kgCm}^{-2}\right), \mathrm{cn}$ is the $\mathrm{C}: \mathrm{N}$ ratio. The term $\frac{M}{c n}$ represents the $\mathrm{N}$ content of the plant against the unitless mass-ratio term in TRIFFID of $\left\{\frac{N_{r}+N_{s}}{N_{l}}\right\}$. The shaping parameterisation for $\mathrm{R}_{\text {pnon-photT }}$ in

10 TRIFFID comes again from the dark-respiration formulation in equation B.3, omitting the $r_{m}$ shaping parameter from LPJ. The differing mass-ratios in these equations have not been reconciled between TRIFFID and LPJGUESS. Therefore the shaping parameter $r_{\mathrm{gT}}$ was calibrated in place of the two parameters $r_{\mathrm{gLPJ}}$ and $r_{\mathrm{mLPJ}}$ in LPJGUESS in order to fit the output curves in Figures 1 and 2. It is notable that $r_{g T}$ with a value of 0.1 is lower than the similar $r_{\text {gLPJ }}(0.5)$ or the value of $r_{g T}$ previously used in TRIFFID, 0.25 (Clark et al. 2011) for vascular plants,

15 and this implies that the values of $\mathrm{f}_{\mathrm{dT}}$ and $\mathrm{r}_{\mathrm{gT}}$ could be more tightly constrained, when more calibration data is available.

In summary, the value of $\mathrm{f}_{\mathrm{d}}$ for TRIFFID in Table 4 has been established for Sphagnum, which is the same as the equivalent parameter in LPJ-GUESS. In this version of the TRIFFID Sphagnum model, parameter $r_{\mathrm{g}}$ is used as a 20 shaping parameter.

\section{B.2 Sphagnum Leaf Area Index}

The model outputs did not fit the field-data of GPP against WTP from both Riutta et al (2007) and Strack et al (2009), without the LAI parameter being changed. Bond-Lamberty \& Gower (2007) measured moss-LAI in a 25 forested peatland, and found that Sphagnum and other boreal mosses have LAIs between 1 and 10. Glenn et al. (2006) measured the LAI of Sphagnum in a nutrient-poor fen as 1. Rydin et al (2006) noted that Sphagnum species 
that form lawns have lower shoot-density than those that form hummocks. The former include the species examined in Riutta et al (2007), the latter include the species in Strack et al (2009). Therefore LAI=1 (equivalent to lower shoot density) was applied to fit the model to data from Riutta et al (2007) (lawn/fen species with lower shootdensity) and this parameter was changed to LAI=3 (equivalent to higher shoot-density) in order to fit the data from

5 Strack et al (2009) (hummock/bog species with higher shoot-density). In addition, it is also plausible that a different desiccation stress function is required for these different Sphagnum species, with different parameters for the equation that defines $\beta_{\text {Sphagnum }}$ in Table 2, but different stress functions have not been developed here.

\section{Code Availability}

We have modified subroutines in the Surface section of the JULES v2.1 model code. This changed code is available

10 at the DOI link in Coppell (2019), for which we obtained permission from the Met Office. We must emphasise that JULES v2.1 is not the latest version of JULES and differs in much of its functionality from the latest version. Permission and license-information to use the whole JULES model is available from http://juleslsm.github.io/access_req/JULES_access.html, from where the complete original JULES v2.1 model may be requested by email.

\section{Author Contribution}

Richard Coppell - developed the simultaneous-function part of the model with EG and designed and implemented all other parts of the model, tuned and tested, and co-wrote the paper with JH.

Emanuel Gloor - developed the simultaneous-function element of the model with RC and proof-read the paper. Joseph Holden - supervised and co-wrote the paper with RC.

\section{Competing Interests}

The authors declare that they have no conflict of interest. 


\section{Acknowledgements}

We would like to thank Andy Baird, water@leeds, School of Geography, University of Leeds, UK, for influential advice on the early direction of the research and the literature base. The following were of great assistance in using the JULES model: Stephen Sitch, water@leeds, School of Geography, University of Leeds, UK (currently at

5 Department of Geography, University of Exeter, UK); Chris Jones, The Hadley Centre for Climate Prediction and Research, Exeter, UK; Doug Clark, The Centre for Ecology and Hydrology, Wallingford, UK; Alan Real \& Dureid El-Moghraby, Information Systems Services, University of Leeds, UK. We are also grateful to Martin Best, The Hadley Centre for Climate Prediction and Research, for giving limited permission to make available our changed JULES code on a DOI link for this paper. Additional thanks go to Sergey Venevsky, School of Geography, 10 University of Leeds, UK (currently at Center for Earth System Science, Tsinghua University, China) and Katherine Arrell for additional supervision. Finally, thanks go to Alice Noble, University of Leeds; Lorna Street, University of Edinburgh and Rita Wania, who was previously at the University of Bristol, for discussions regarding Sphagnum and moss carbon cycling. R. Coppell was funded by a NERC scholarship NE/F008341/1 supported by the Met Office Hadley Centre as CASE partner, which led to the technical support received from Chris Jones and Doug

15 Clark, above. Richard Coppell also acknowledges his cousin, David Rogers, for proof-reading and the Additional Learning Support department at Leeds City College for employment whilst continuing this work, and in particular Steve Brown. This work was undertaken on ARC1, part of the High Performance Computing facilities at the University of Leeds, UK. 


\section{References}

Allaby, M.: Oxford Dictionary of Plant Sciences, 2nd ed., Oxford University Press, Oxford, 2006.

Amthor, J. S., and Baldocchi, D. D.: Terrestrial Higher Plant Respiration and Net Primary Production. In Terrestrial

Global Productivity, in: Terrestrial Global Productivity, edited by: Roy, J., Saugier, B., and Mooney, H. A.,

5 Academic Press Inc., San Diego, USA, 33-59, 2001.

Baird, A. J., Belyea, L. R., and Morris, P. J.: Upscaling of Peatland-Atmosphere Fluxes of Methane: Small-Scale Heterogeneity in Process Rates and the Pitfalls of "Bucket-and-Slab" Models, Carbon Cycling in Northern Peatlands, 184, 37-53, 10.1029/2008gm000826, 2009.

Begon, M., Townsend, C. R., and Harper, J. L.: Ecology From Individuals to Ecosystems, 4th ed., Wiley-Blackwell, Malden, MA ; Oxford, 2006.

Belyea, L. R., and Baird, A. J.: Beyond "The limits to peat bog growth": Cross-scale feedback in peatland development, Ecological Monographs, 76, 299-322, 10.1890/0012-9615(2006)076[0299:btltpb]2.0.co;2, $2006 a$.

Belyea, L. R., and Baird, A. J.: Beyond "The limits to peat bog growth": Cross-scale feedback in peatland development, Ecological Monographs, 76, 299-322, 10.1890/0012-9615(2006)076[0299:btltpb]2.0.co;2, 2006 b.

20 Belyea, L. R.: Nonlinear Dynamics of Peatlands and Potential Feedbacks on the Climate System, Carbon Cycling in Northern Peatlands, 184, 5-18, 10.1029/2008gm000829, 2009.

Beringer, J., Lynch, A. H., Chapin, F. S., Mack, M., and Bonan, G. B.: The representation of arctic soils in the land surface model: The importance of mosses, Journal of Climate, 14, 3324-3335, 10.1175/152025 0442(2001)014<3324:troasi>2.0.co;2, 2001.

Best, M. J., Pryor, M., Clark, D. B., Rooney, G. G., Essery, R. L. H., Menard, C. B., Edwards, J. M., Hendry, M. A., Porson, A., Gedney, N., Mercado, L. M., Sitch, S., Blyth, E., Boucher, O., Cox, P. M., Grimmond, C. S. B., 
and Harding, R. J.: The Joint UK Land Environment Simulator (JULES), model description - Part 1: Energy and water fluxes, Geoscientific Model Development, 4, 677-699, 10.5194/gmd-4-677-2011, 2011.

Beven, K.: Causal models as multiple working hypotheses about environmental processes, Comptes Rendus

Geoscience, 344, 77-88, 10.1016/j.crte.2012.01.005, 2012.

Bewley, J. D., Halmer, P., Krochko, J., and Winner, W. E.: Metabolism of a drought-tolerant and a droughtsensitive moss: respiration, ATP synthesis and carbohydrate status, in: Dry Biological Systems, edited by: Crowe, J. H., and Clegg, J. S., Academic Press, Inc., New York, 185-205, 1978.

10

Bond-Lamberty, B., Wang, C. K., and Gower, S. T.: Net primary production and net ecosystem production of a boreal black spruce wildfire chronosequence, Global Change Biology, 10, 473-487, 10.1111/j.15298817.2003.0742.x, 2004 .

15 Bragg, O., and Lindsay, R.: Strategy and Action Plan for Mire and Peatland Conservation in Central Europe, Wageningen, The Netherlands, 94 pp., 2003.

Brovkin, V., Ganopolski, A., and Svirezhev, Y.: A continuous climate-vegetation classification for use in climatebiosphere studies, Ecological Modelling, 101, 251-261, 10.1016/s0304-3800(97)00049-5, 1997.

Bu, Z. J., Zheng, X. X., Rydin, H., Moore, T., and Ma, J. Z.: Facilitation vs. competition: Does interspecific interaction affect drought responses in Sphagnum?, Basic and Applied Ecology, 14, 574-584, 10.1016/j.baae.2013.08.002, 2013.

25 Carleton, T. J., and Dunham, K. M. M.: Distillation in a boreal mossy forest floor, Canadian Journal of Forest Research-Revue Canadienne De Recherche Forestiere, 33, 663-671, 10.1139/x02-197, 2003.

Charman, D.: Peatlands and Environmental Change, Wiley, Chichester, UK, 301 pp., 2002. 
Charman, D. J., Beilman, D. W., Blaauw, M., Booth, R. K., Brewer, S., Chambers, F. M., Christen, J. A., GallegoSala, A., Harrison, S. P., Hughes, P. D. M., Jackson, S. T., Korhola, A., Mauquoy, D., Mitchell, F. J. G., Prentice, I. C., van der Linden, M., De Vleeschouwer, F., Yu, Z. C., Alm, J., Bauer, I. E., Corish, Y. M. C., Garneau, M., Hohl, V., Huang, Y., Karofeld, E., Le Roux, G., Loisel, J., Moschen, R., Nichols, J. E., Nieminen, T. M., 5 MacDonald, G. M., Phadtare, N. R., Rausch, N., Sillasoo, U., Swindles, G. T., Tuittila, E. S., Ukonmaanaho, L., Valiranta, M., van Bellen, S., van Geel, B., Vitt, D. H., and Zhao, Y.: Climate-related changes in peatland carbon accumulation during the last millennium, Biogeosciences, 10, 929-944, 10.5194/bg-10-929-2013, 2013.

Clark, D., Harris, P., Pryor, M., and Hendry, M.: Joint UK Land Environment Simulator (JULES) Version 2.2 User 10 Manual. The Centre for Ecology \& Hydrology, UK. Hadley Centre for Climate Prediction and Research, UK., Wallingford, Oxfordhire, UK, 2010.

Clark, D. B., and Gedney, N.: Representing the effects of subgrid variability of soil moisture on runoff generation in a land surface model, Journal of Geophysical Research-Atmospheres, 113, 10.1029/2007jd008940, 2008.

Clark, D. B., Mercado, L. M., Sitch, S., Jones, C. D., Gedney, N., Best, M. J., Pryor, M., Rooney, G. G., Essery, R. L. H., Blyth, E., Boucher, O., Harding, R. J., Huntingford, C., and Cox, P. M.: The Joint UK Land Environment Simulator (JULES), model description - Part 2: Carbon fluxes and vegetation dynamics, Geoscientific Model Development, 4, 701-722, 10.5194/gmd-4-701-2011, 2011.

Clymo, R. S., and Hayward, P. M.: The Ecology of Sphagnum, in: Bryophyte Ecology, edited by: Smith, A. I. E., Springer, Netherlands, 229-289, 1982.

Coppell, R.: JULES DGVM modified SURFACE subroutines only, incorporating Sphagnum PFT func. University of Leeds. [Dataset]. https://doi.org/10.5518/567, 2019.

Cox, P. M., Huntingford, C., and Harding, R. J.: A canopy conductance and photosynthesis model for use in a GCM land surface scheme, Journal of Hydrology, 212, 79-94, 10.1016/s0022-1694(98)00203-0, 1998. 
Cox, P. M., Betts, R. A., Bunton, C. B., Essery, R. L. H., Rowntree, P. R., and Smith, J.: The impact of new land surface physics on the GCM simulation of climate and climate sensitivity, Climate Dynamics, 15, 183-203, 10.1007/s003820050276, 1999.

5 Cox, P. M., Betts, R. A., Jones, C. D., Spall, S. A., and Totterdell, I.: Modelling vegetation and the carbon cycle as interactive elements of the climate system. In: Hadley Centre Technical Notes, 2001.

Dimitrov, D. D., Grant, R. F., Lafleur, P. M., and Humphreys, E. R.: Modeling the effects of hydrology on gross primary productivity and net ecosystem productivity at Mer Bleue bog, Journal of Geophysical Research10 Biogeosciences, 116, 10.1029/2010jg001586, 2011.

Druel, A., Peylin, P., Krinner, G., Ciais, P., Viovy, N., Peregon, A., Bastrikov, V., Kosykh, N., and MironychevaTokareva, N.: Towards a more detailed representation of high-latitude vegetation in the global land surface model ORCHIDEE (ORC-HL-VEGv1.0), Geoscientific Model Development, 10, 4693-4722, 10.5194/gmd-10-4693$152017,2017$.

Euskirchen, E. S., McGuire, A. D., Chapin, F. S., Yi, S., and Thompson, C. C.: Changes in vegetation in northern Alaska under scenarios of climate change, 2003-2100: implications for climate feedbacks, Ecological Applications, 19, 1022-1043, 10.1890/08-0806.1, 2009.

Foley, J. A., Prentice, I. C., Ramankutty, N., Levis, S., Pollard, D., Sitch, S., and Haxeltine, A.: An integrated biosphere model of land surface processes, terrestrial carbon balance, and vegetation dynamics, Global Biogeochemical Cycles, 10, 603-628, 10.1029/96gb02692, 1996.

25 Frolking, S., Roulet, N. T., Moore, T. R., Richard, P. J. H., Lavoie, M., and Muller, S. D.: Modeling northern peatland decomposition and peat accumulation, Ecosystems, 4, 479-498, 10.1007/s10021-001-0105-1, 2001. 
Frolking, S., Roulet , N., and Lawrence, D.: Issues related to incorporating northern peatlands into Global Climate Models., in: Carbon cycling in northern peatlands. American Geophysical Union Monograph, edited by: Baird AJ, B. L., Comas X, Reeve AS, Slater LD, 184, American Geophysical Union, Washington DC, 19-36, 2009.

5 Gao, Q., Yu, M., and Zhou, C.: Detecting the Differences in Responses of Stomatal Conductance to Moisture Stresses between Deciduous Shrubs and Artemisia Subshrubs, PlosOne, 8, e84200, 10.1371/journal.pone.0084200, 2013.

Gerdol, R., Bonora, A., Marchesini, R., Gualandri, R., and Pancaldi, S.: Growth response of Sphagnum 10 capillifolium to nighttime temperature and nutrient level: Mechanisms and implications for global change, Arctic and Alpine Research, 30, 388-395, 10.2307/1552011, 1998.

Glenn, A. J., Flanagan, L. B., Syed, K. H., and Carlson, P. J.: Comparison of net ecosystem $\mathrm{CO}_{2}$ exchange in two peatlands in western Canada with contrasting dominant vegetation, Sphagnum and Carex, Agricultural and Forest 15 Meteorology, 140, 115-135, 10.1016/j.agrformet.2006.03.020, 2006.

Hajek, T., and Beckett, R. P.: Effect of water content components on desiccation and recovery in Sphagnum mosses, Annals of Botany, 101, 165-173, 10.1093/aob/mcm287, 2008.

20 Hajek, T., Ballance, S., Limpens, J., Zijlstra, M., and Verhoeven, J. T. A.: Cell-wall polysaccharides play an important role in decay resistance of Sphagnum and actively depressed decomposition in vitro, Biogeochemistry, 103, 45-57, 10.1007/s10533-010-9444-3, 2011.

Harper, A.B., Wiltshire, A.J., Cox, P.M., Friedlingstein, P., Jones, C.D., Mercado, L.M., Sitch, S., Williams, K., 25 Duran-Rojas, C., 2018. Vegetation distribution and terrestrial carbon cycle in a carbon cycle configuration of JULES4.6 with new plant functional types. Geoscientific Model Development 11, 2857-2873. 
Haxeltine, A., and Prentice, I. C.: BIOME3: An equilibrium terrestrial biosphere model based on ecophysiological constraints, resource availability, and competition among plant functional types, Global Biogeochemical Cycles, 10, 693-709, 10.1029/96gb02344, 1996.

5 Hayman, G. D., O'Connor, F. M., Dalvi, M., Clark, D. B., Gedney, N., Huntingford, C., Prigent, C., Buchwitz, M., Schneising, O., Burrows, J. P., Wilson, C., Richards, N., and Chipperfield, N.: Comparison of the HadGEM2 climate-chemistry model against in-situ and SCIAMACHY atmospheric methane data, Atmos. Chem. Phys. Discuss., 14, 12967-13020, 10.5194/acpd-14-12967-2014, 2014.

10 Hayward, P. M., and Clymo, R. S.: Profiles of water-content and pore-size in Sphagnum and peat, and their relation to peat bog ecology, Proceedings of the Royal Society Series B-Biological Sciences, 215, 299-325, 10.1098/rspb.1982.0044, 1982.

Hughes, J. K., Valdes, P. J., and Betts, R. A.: Dynamical properties of the TRIFFID dynamic global vegetation 15 model. In: Hadley Centre Technical Notes, 56, 2004.

Jobbagy, E. G., and Jackson, R. B.: The vertical distribution of soil organic carbon and its relation to climate and vegetation, Ecological Applications, 10, 423-436, 10.2307/2641104, 2000.

20 Johnson, M. G., Granath, G., Tahvanainen, T., Pouliot, R., Stenoien, H. K., Rochefort, L., Rydin, H., and Shaw, A. J.: Evolution of niche preference in Sphagnum peat mosses, Evolution, 69, 90-103, 10.1111/evo.12547, 2015.

Kangas, L., Maanavilja, L., Hajek, T., Juurola, E., Chimner, R. A., Mehtatalo, L., and Tuittila, E. S.: Photosynthetic traits of Sphagnum and feather moss species in undrained, drained and rewetted boreal spruce swamp forests, 25 Ecology and Evolution, 4, 381-396, 10.1002/ece3.939, 2014.

Lamers, L. P. M., Farhoush, C., Van Groenendael, J. M., and Roelofs, J. G. M.: Calcareous groundwater raises bogs; the concept of ombrotrophy revisited, Journal of Ecology, 87, 639-648, 10.1046/j.1365-2745.1999.00380.x, 1999. 
Laurent, J. M., Bar-Hen, A., Francois, L., Ghislain, M., and Cheddadi, R.: Refining vegetation simulation models: From plant functional types to bioclimatic affinity groups of plants, Journal of Vegetation Science, 15, 739-746, 10.1111/j.1654-1103.2004.tb02316.x, 2004.

Leuning, R.: A critical-appraisal of a combined stomatal-photosynthesis model for C-3 plants, Plant Cell and Environment, 18, 339-355, 10.1111/j.1365-3040.1995.tb00370.x, 1995.

Limpens, J., Berendse, F., Blodau, C., Canadell, J. G., Freeman, C., Holden, J., Roulet, N., Rydin, H., and

10 Schaepman-Strub, G.: Peatlands and the carbon cycle: from local processes to global implications - a synthesis, Biogeosciences, 5, 1475-1491, 2008.

Lindo, Z., and Gonzalez, A.: The Bryosphere: An Integral and Influential Component of the Earth's Biosphere, Ecosystems, 13, 612-627, 10.1007/s10021-010-9336-3, 2010.

Loisel, J., Garneau, M., and Helie, J. F.: Modern Sphagnum delta C-13 signatures follow a surface moisture gradient in two boreal peat bogs, James Bay lowlands, Quebec, Journal of Quaternary Science, 24, 209-214, 10.1002/jqs.1221, 2009.

20 Loisel, J., Gallego-Sala, A. V., and Yu, Z.: Global-scale pattern of peatland Sphagnum growth driven by photosynthetically active radiation and growing season length, Biogeosciences, 9, 2737-2746, 10.5194/bg-9-27372012, 2012.

Murray, K. J., Harley, P. C., Beyers, J., Walz, H., and Tenhunen, J. D.: Water-content effects on photosynthetic 25 response of Sphagnum mosses from the foothills of the Philip Smith Mountains, Alaska, Oecologia, 79, 244-250, 10.1007/bf00388484, 1989.

O'Connor, F. M., Boucher, O., Gedney, N., Jones, C. D., Folberth, G. A., Coppell, R., Friedlingstein, P., Collins, W. J., Chappellaz, J., Ridley, J., and Johnson, C. E.: Possible role of wetlands, permafrost, and methane hydrates 
in the methane cycle under future climate change: a review, Reviews of Geophysics, 48, 10.1029/2010rg000326, 2010.

Pope, V. D., Gallani, M. L., Rowntree, P. R., and Stratton, R. A.: The impact of new physical parametrizations in

Prentice, I. C., Cramer, W., Harrison, S. P., Leemans, R., Monserud, R. A., and Solomon, A. M.: A global biome model based on plant physiology and dominance, soil properties and climate., Journal of Biogeography, 19, 117 $134,10.2307 / 2845499,1992$.

10

Price, G. D., McKenzie, J. E., Pilcher, J. R., and Hoper, S. T.: Carbon-isotope variation in Sphagnum form hummock-hollow complexes: Implications for Holocene climate reconstruction, Holocene, 7, 229-233, 10.1177/095968369700700211, 1997.

15 Proctor, M. C. F., Raven, J. A., and Rice, S. K.: Stable carbon isotope discrimination measurements in Sphagnum and other bryophytes - physiological and ecological implications, Journal of Bryology, 17, 193-202, 1992.

Qiu, C. J., Zhu, D., Ciais, P., Guenet, B., Krinner, G., Peng, S. S., Aurela, M., Bernhofer, C., Brummer, C., BretHarte, S., Chu, H. S., Chen, J. Q., Desai, A. R., Dusek, J., Euskirchen, E. S., Fortuniak, K., Flanagan, L. B., Friborg, 20 T., Grygoruk, M., Gogo, S., Grunwald, T., Hansen, B. U., Holl, D., Humphreys, E., Hurkuck, M., Kiely, G., Klatt, J., Kutzbach, L., Largeron, C., Laggoun-Defarge, F., Lund, M., Lafleur, P. M., Li, X. F., Mammarella, I., Merbold, L., Nilsson, M. B., Olejnik, J., Ottosson-Lofvenius, M., Oechel, W., Parmentier, F. J. W., Peichl, M., Pirk, N., Peltola, O., Pawlak, W., Rasse, D., Rinne, J., Shaver, G., Schmid, H. P., Sottocornola, M., Steinbrecher, R., Sachs, T., Urbaniak, M., Zona, D., and Ziemblinska, K.: ORCHIDEE-PEAT (revision 4596), a model for northern 25 peatland $\mathrm{CO}_{2}$, water, and energy fluxes on daily to annual scales, Geoscientific Model Development, 11, 497-519, 10.5194/gmd-11-497-2018, 2018.

Randall, D. A., Dazlich, D. A., Zhang, C., Denning, A. S., Sellers, P. J., Tucker, C. J., Bounoua, L., Los, S. O., Justice, C. O., and Fung, I.: A revised land surface parameterization (SiB2) for GCMs .3. The greening of the 
Colorado State University general circulation model, Journal of Climate, 9, 738-763, 10.1175/15200442(1996)009<0738:arlspf>2.0.co;2, 1996.

Rice, S. K.: Variation in carbon isotope discrimination within and among Sphagnum species in a temperate wetland,

Oecologia, 123, 1-8, 10.1007/s004420050983, 2000.

Riutta, T., Laine, J., and Tuittila, E. S.: Sensitivity of $\mathrm{CO}_{2}$ exchange of fen ecosystem components to water level variation, Ecosystems, 10, 718-733, 10.1007/s10021-007-9046-7, 2007.

10 Rydin, H.: Effect of water level on desiccation of Sphagnum in relation to surrounding Sphagna, Oikos, 45, 374$379,10.2307 / 3565573,1985$.

Rydin, H.: Competition and niche separation in Sphagnum, Canadian Journal of Botany-Revue Canadienne De Botanique, 64, 1817-1824, 1986.

15

Rydin, H., Gunnarsson, U., and Sundberg, S.: The Role of Sphagnum in Peatland Development and Persistence., in: Boreal Peatland Ecosystems, edited by: Wieder , R. K., Vitt , D.H., Springer- Verlag, Berlin, 47-65, 2006.

Rydin, H., and Jeglum, J. K.: The biology of peatlands, Oxford University Press, Oxford, 1 pp., 2006.

Sellers, P. J., Los, S. O., Tucker, C. J., Justice, C. O., Dazlich, D. A., Collatz, G. J., and Randall, D. A.: A revised land surface parameterization $(\mathrm{SiB} 2)$ for atmospheric GCMs .2. The generation of global fields of terrestrial biophysical parameters from satellite data, Journal of Climate, 9, 706-737, 10.1175/15200442(1996)009<0706:arlspf>2.0.co;2, 1996a.

Sellers, P. J., Randall, D. A., Collatz, G. J., Berry, J. A., Field, C. B., Dazlich, D. A., Zhang, C., Collelo, G. D., and Bounoua, L.: A revised land surface parameterization (SiB2) for atmospheric GCMs .1. Model formulation, Journal of Climate, 9, 676-705, 10.1175/1520-0442(1996)009<0676:arlspf>2.0.co;2, 1996b. 
Sitch, S., Smith, B., Prentice, I. C., Arneth, A., Bondeau, A., Cramer, W., Kaplan, J. O., Levis, S., Lucht, W., Sykes, M. T., Thonicke, K., and Venevsky, S.: Evaluation of ecosystem dynamics, plant geography and terrestrial carbon cycling in the LPJ dynamic global vegetation model, Global Change Biology, 9, 161-185, 10.1046/j.13652486.2003.00569.x, 2003.

Skre, O., and Oechel, W. C.: Moss functioning in different taiga ecosystems in interior Alaska .1. Seasonal, phenotypic, and drought effects on photosynthesis and response patterns, Oecologia, 48, 50-59, 10.1007/bf00346987, 1981.

10 Smolders, A. J. P., Tomassen, H. B. M., Pijnappel, H. W., Lamers, L. P. M., and Roelofs, J. G. M.: Substratederived $\mathrm{CO}_{2}$ is important in the development of Sphagnum spp, New Phytologist, 152, 325-332, 10.1046/j.0028646X.2001.00261.x, 2001.

Sonnentag, O., Chen, J. M., Roulet, N. T., Ju, W., and Govind, A.: Spatially explicit simulation of peatland 15 hydrology and carbon dioxide exchange: Influence of mesoscale topography, Journal of Geophysical ResearchBiogeosciences, 113, 10.1029/2007jg000605, 2008.

Strack, M., Waddington, J. M., Lucchese, M. C., and Cagampan, J. P.: Moisture controls on $\mathrm{CO}_{2}$ exchange in a Sphagnum-dominated peatland: results from an extreme drought field experiment, Ecohydrology, 2, 454-461, 20 10.1002/eco.68, 2009.

Street, L. E., Subke, J.-A., Sommerkorn, M., Sloan, V., Ducrotoy, H., Phoenix, G. K., and Williams, M.: The role of mosses in carbon uptake and partitioning in arctic vegetation, New Phytologist, 199, 163-175, 10.1111/nph.12285, 2013.

Thompson, D. K., and Waddington, J. M.: Sphagnum under pressure: towards an ecohydrological approach to examining Sphagnum productivity, Ecohydrology, 1, 299-308, 10.1002/eco.31, 2008. 
Vanbreemen, N.: HOW SPHAGNUM BOGS DOWN OTHER PLANTS, Trends in Ecology \& Evolution, 10, 270275, 10.1016/0169-5347(95)90007-1, 1995.

Waddington, J. M., and Roulet, N. T.: Atmosphere-wetland carbon exchanges: Scale dependency of $\mathrm{CO}_{2}$ and $\mathrm{CH}_{4}$ exchange on the developmental topography of a peatland, Global Biogeochemical Cycles, 10, 233-245, 10.1029/95gb03871, 1996.

Wania, R., Ross, I., and Prentice, I. C.: Integrating peatlands and permafrost into a dynamic global vegetation model: 1. Evaluation and sensitivity of physical land surface processes, Global Biogeochemical Cycles, 23, $10 \quad 10.1029 / 2008 \mathrm{gb} 003412,2009 \mathrm{a}$.

Wania, R., Ross, I., and Prentice, I. C.: Integrating peatlands and permafrost into a dynamic global vegetation model: 2. Evaluation and sensitivity of vegetation and carbon cycle processes, Global Biogeochemical Cycles, 23, 15, 10.1029/2008gb003413, 2009b.

15

Wieder, R. K.: Primary production in boreal peatlands, Ecological Studies, 188, 145-164, 2006.

Williams, T. G., and Flanagan, L. B.: Measuring and modelling environmental influences on photosynthetic gas exchange in Sphagnum and Pleurozium, Plant Cell and Environment, 21, 555-564, 10.1046/j.13653040.1998.00292.x, 1998.

Woodward, F. I.: Predictions and measurements of the maximum photosynthetic rate, Amax, at the global scale., in: Ecophysiology: photosynthesis, edited by: Schulze, E. D., and Caldwell, M. M., Springer-Verlag, Berlin, 491$509,1994$.

Yu, Z. C., Loisel, J., Brosseau, D. P., Beilman, D. W., and Hunt, S. J.: Global peatland dynamics since the Last Glacial Maximum, Geophysical Research Letters, 37, 10.1029/2010g1043584, 2010. 
https://doi.org/10.5194/gmd-2019-51

Preprint. Discussion started: 9 July 2019

(c) Author(s) 2019. CC BY 4.0 License.

(c) (i)

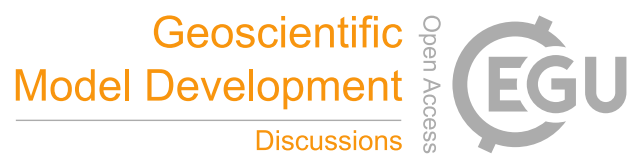

Yu, Z. C.: Holocene carbon flux histories of the world's peatlands: Global carbon-cycle implications, Holocene, 21, 761-774, 10.1177/0959683610386982, 2011.

Yurova, A., Wolf, A., Sagerfors, J., and Nilsson, M.: Variations in net ecosystem exchange of carbon dioxide in a

5 boreal mire: Modeling mechanisms linked to water table position, Journal of Geophysical ResearchBiogeosciences, 112, 10.1029/2006jg000342, 2007. 